\title{
Evaluation of industrial promoted agroforestry in Andhra Pradesh and Madhya Pradesh, India
}

\author{
Brian D. McDonald \\ West Virginia University
}

Follow this and additional works at: https://researchrepository.wvu.edu/etd

\section{Recommended Citation}

McDonald, Brian D., "Evaluation of industrial promoted agroforestry in Andhra Pradesh and Madhya Pradesh, India" (2009). Graduate Theses, Dissertations, and Problem Reports. 2819.

https://researchrepository.wvu.edu/etd/2819

This Thesis is protected by copyright and/or related rights. It has been brought to you by the The Research Repository @ WVU with permission from the rights-holder(s). You are free to use this Thesis in any way that is permitted by the copyright and related rights legislation that applies to your use. For other uses you must obtain permission from the rights-holder(s) directly, unless additional rights are indicated by a Creative Commons license in the record and/ or on the work itself. This Thesis has been accepted for inclusion in WVU Graduate Theses, Dissertations, and Problem Reports collection by an authorized administrator of The Research Repository @ WVU. For more information, please contact researchrepository@mail.wvu.edu. 


\title{
Evaluation of Industrial Promoted Agroforestry in Andhra Pradesh and Madhya Pradesh, India
}

\author{
Brian D. McDonald
}

Thesis submitted to the Davis College of Agriculture, Natural Resources and Design

At West Virginia University In partial fulfillment of the requirements

For the degree of

Master of Science

In

Forestry

\author{
Kathryn Arano, Ph.D., Chair \\ David McGill, PhD. \\ Kathryn Piatek, Ph.D. \\ Ben Spong, Ph.D. \\ Department of Forestry
}

\author{
Morgantown, West Virginia \\ 2009
}




\section{Abstract \\ Evaluation of Industrial Promoted Agroforestry in Andhra Pradesh and Madhya Pradesh, India}

\section{Brian D. McDonald}

In many parts of the world, pulp and paper companies are becoming heavily dependent on private agroforestry schemes. With growing demand for wood fiber and limited commercial land to grow it on, the forest industry is continually turning to private farmers and individuals to contract timber. In order to alleviate this problem, many companies have turned to out-grower schemes to supply wood to the mills. Local farmers now have the opportunity to benefit from company extension and supplies, and in return, the company can guarantee its supply of raw materials.

A recent trend in agriculture is adding trees to farmers' traditional croplands or agroforestry, in which farmers typically select fast growing tree species that can be harvested after only a few years. However, careful consideration of the economics of such conversion is important to farmers in order to make informed decisions to convert their farms to forestry use. Since this is a new practice in many regions of the world, there is little data available, especially to farmers, on the financial feasibility of these agroforestry systems.

This study investigates commercially promoted agroforestry schemes in two states in India. Specifically, this study evaluates the financial feasibility of agroforestry techniques employed by farmers in Andhra Pradesh and Madhya Pradesh, India and examines factors affecting the financial feasibility of agroforestry schemes in these regions.

The data for this study were collected by personal interviews of 47 farmers, in the summer of 2009. To examine the economic feasibility of converting traditional agricultural lands to agroforestry or farm forestry, standard financial criteria were calculated such as Net Present Value (NPV), Benefit-Cost Ratio (BCR), Internal Rate of Return (IRR), Equivalent Annual Income (EAI), and Land Equivalency Value (LEV). Results show that the agroforestry systems adopted by farmers in both regions are profitable at all discount rates applied.

Regression analysis was carried out to understand how NPV is influenced by farmer characteristics (education, gender), costs of farming practices (plowing cost, fertilizer cost, planting cost, etc.), revenues from both forestry and agricultural products (eucalyptus revenue, intercrop revenue), agroforestry practices (spacing, trees per acre, number of intercrops, type of intercrops), and farm characteristics (size, location). Results show that region, the starting year of agroforesty establishment, plowing cost, irrigation cost, spacing, trees per acre, number of intercrops used, type of intercrops used, intercrop cost, intercrop revenues, and eucalyptus plantation revenues are influential factors in determining the financial feasibility of converting traditional croplands into agroforestry systems. 


\section{Acknowledgements}

I would first like to thank my family and friends for all of their support. Without their support and guidance none of this would have been possible.

I would like to thank Dr. Arano and my committee members for all of their help and support as well. Without their introduction to the idea of international forestry, this project, and my interest in studying for a master's degree would have never happened. Without all of their support and interest in me and my research, before, during and after this project, it never would have been possible.

My many thanks to Dr. Suvarna, Director, Andhra Pradesh Forest Academy and the entire staff of the forest academy for treating me like family and helping with every last detail to make my stay comfortable and extremely beneficial. Without Dr. Suvarna, again, this project would not have been possible. Also, for the staff of the forest academy, for everything they did, thank you.

Thank you to Mr. S.N. Rao and the entire staff of ITC PSPD for their incredible help and hospitality. Spending long hours in the car and in the field was no easy task, but the entire staff made it a wonderful experience.

Last, but certainly not least, thank you to all the farmers who I interviewed. Obviously, without them, this project would never have happened. The hospitality I was shown was absolutely amazing. There was hardly a farm that I visited where I was not invited in for tea, or cookies or even dinner. 


\section{Contents}

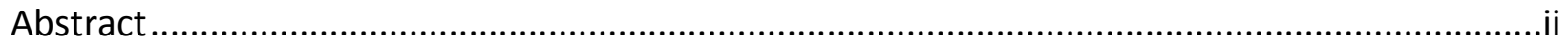

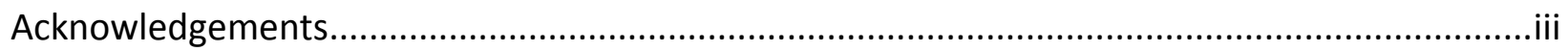

Table of Figures .............................................................................................................

List of Tables .............................................................................................................. vii

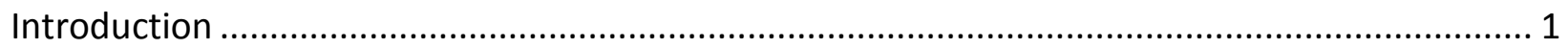

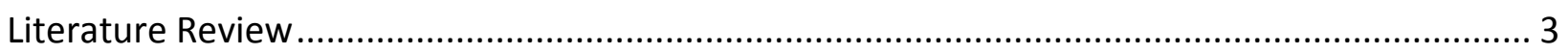

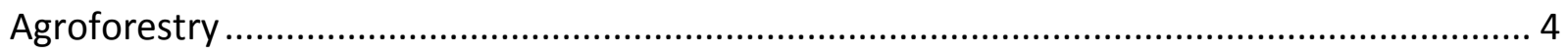

Advantages and Disadvantages of Agroforestry ................................................................. 6

Eucalyptus as a Tree Crop for Agroforestry ................................................................... 8

Role of Pulp and Paper Industry in Agroforestry ............................................................. 9

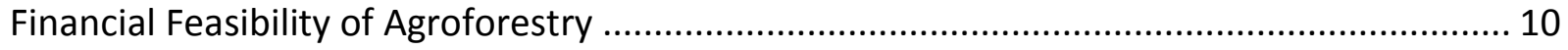

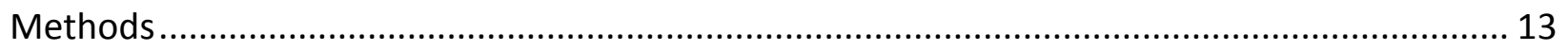

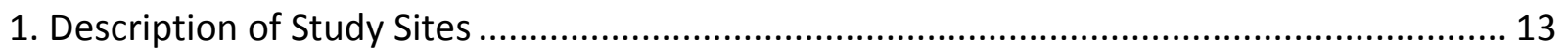

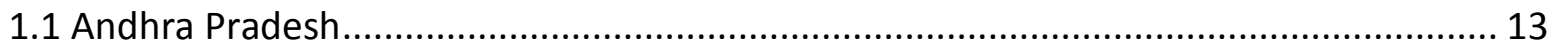

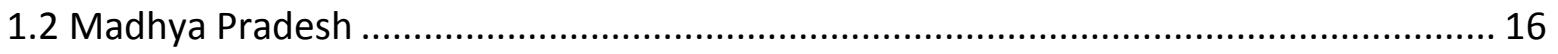

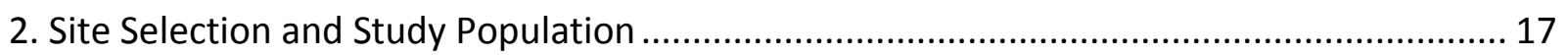

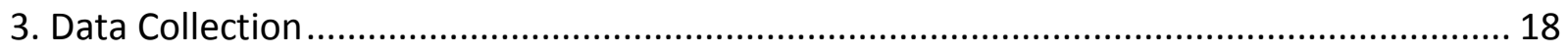

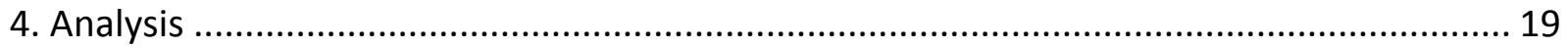

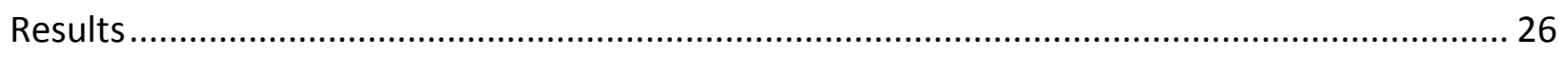

1. Personal Interview Response........................................................................................... 26

3. Demographic Characteristics of Farmers Interviewed ………………………................. 27

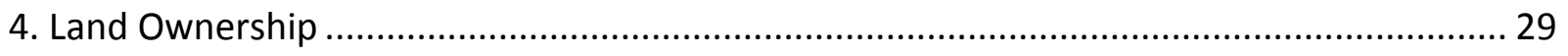

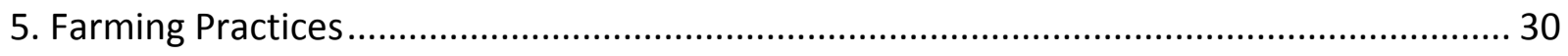




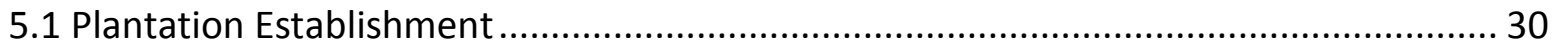

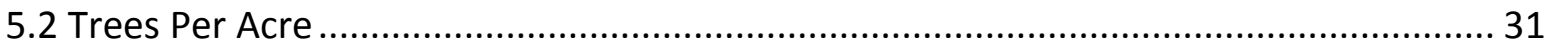

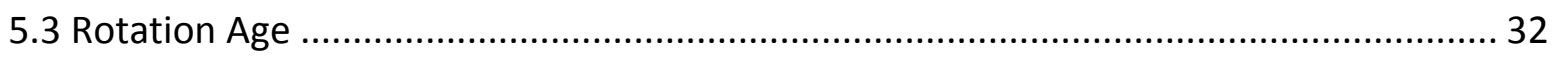

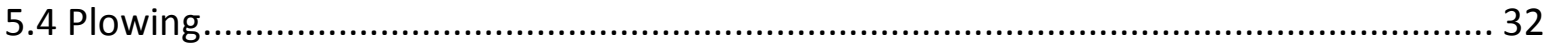

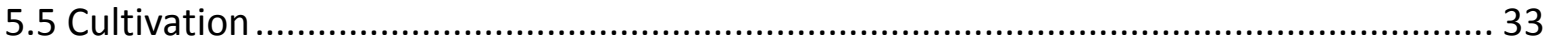

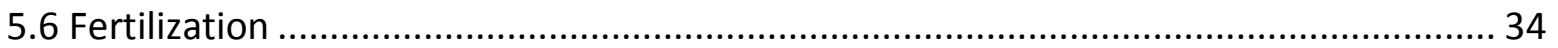

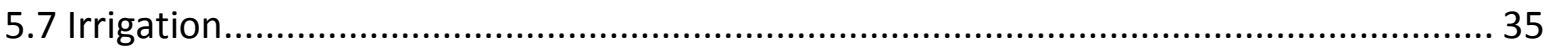

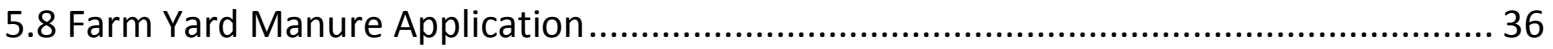

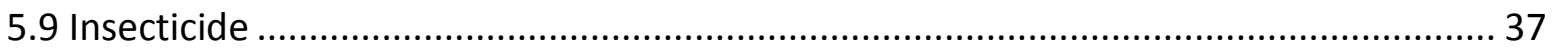

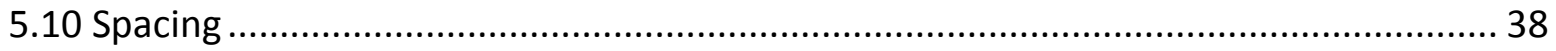

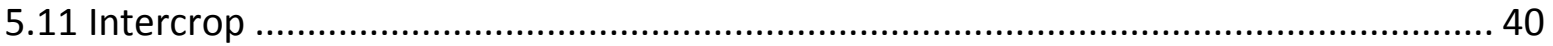

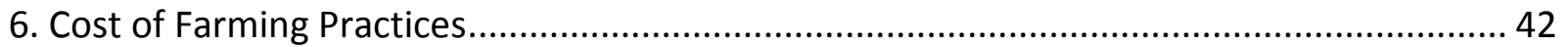

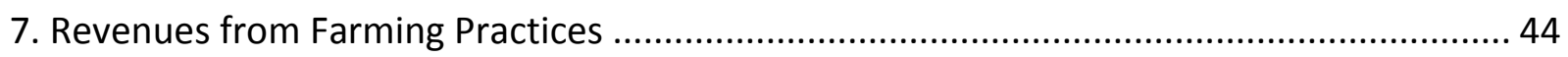

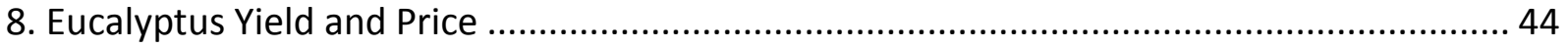

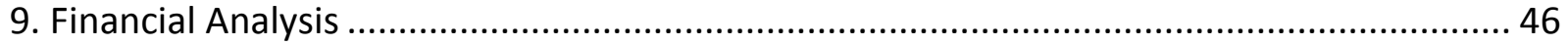

10. Factors Affecting Financial Feasibility of Agroforestry ........................................... 47

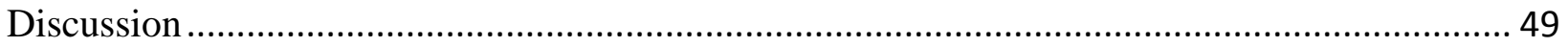

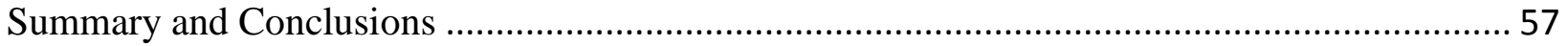

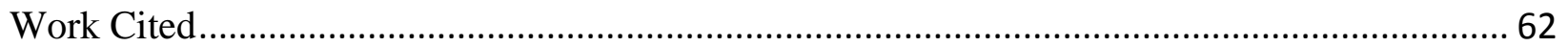

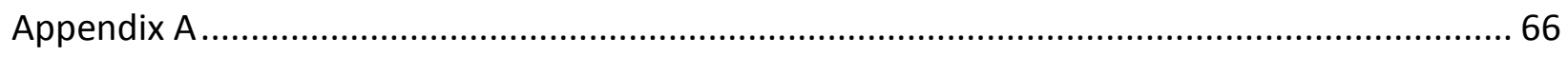

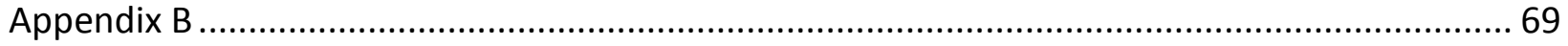




\section{Table of Figures}

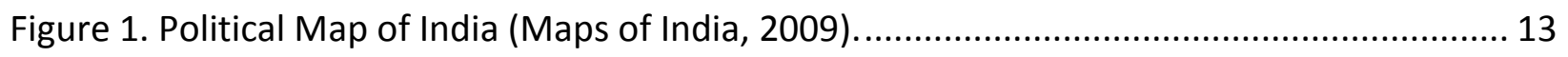

Figure 2. South West Monsoon of India (Maps of India, 2009)........................................... 14

Figure 3. North East Monsoon of India (Maps of India, 2009). ............................................ 15

Figure 4. Annual Temperature of India (Maps of India, 2009).......................................... 15

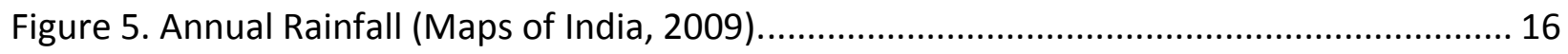

Figure 6. Distribution of farmer by region, Andhra Pradesh and Madhya Pradesh, India, 2009. 26

Figure 7. Distribution of farmer by village, Andhra Pradesh and Madhya Pradesh, India, 2009. 27

Figure 8. Distribution of farmer by education, Andhra Pradesh and Madhya Pradesh, India, 2009. *Statistically significant at .05 level using Chi-Square test........................................... 28

Figure 9. Distribution of farmer by gender, Andhra Pradesh and Madhya Pradesh, India, 2009.29

Figure 10. Distribution of starting year of planting by farmer, Andhra Pradesh and Madhya Pradesh, India, 2009. *Not statistically significant at .05 level using Chi-Square test. .............. 31

Figure 11. Distribution of farmers who conducted plowing, Andhra Pradesh and Madhya Pradesh, India, 2009. *Statistically significant at .05 level using Chi-Square test..................... 33

Figure 12. Distribution of farmers who conducted cultivation, Andhra Pradesh and Madhya Pradesh, India, 2009. * Not statistically significant at .05 level using Chi-Square test................ 34

Figure 13. Distribution of farmers who applied fertilizer, Andhra Pradesh and Madhya Pradesh, India, 2009. *Statistically significant at .05 level using Chi-Square test................................... 35

Figure 14. Distribution of farmers who conducted irrigation, Andhra Pradesh and Madhya Pradesh, India, 2009. *Not statistically significant at .05 level using Chi-Square test. .............. 36

Figure 15. Distribution of farmers who applied farm yard manure, Andhra Pradesh and Madhya Pradesh, India, 2009. *Not statistically significant at .05 level using Chi-Square test.

Figure 16. Distribution of farmers who applied insecticide, Andhra Pradesh and Madhya Pradesh, India, 2009. *Not statistically significant at .05 level using Chi-Square test.

Figure 17. Distribution of farmers by spacing option used, Andhra Pradesh and Madhya Pradesh, India, 2009. *Statistically significant at .05 level using Chi-Square test. 
Figure 18. Distribution of farmers who conducted intercropping, Andhra Pradesh and Madhya Pradesh, India, 2009. *Not statistically significant at .05 level using Chi-Square test. ............... 40

Figure 19. Distribution of farmers by number of intercrops applied, Andhra Pradesh and Madhya Pradesh, India, 2009. *Statistically significant at .05 level using Chi-Square test......... 41 


\section{List of Tables}

Table 1. Cost and revenue estimates used in evaluating financial feasibility of converting traditional croplands into agroforestry in Andhra Pradesh and Madhya Pradesh, India, 2009. . 22

Table2: Description of the variables used in the regression model that examines the factors affecting financial feasibility of converting traditional farms into agroforestry plantation in Andhra Pradesh and Madhya Pradesh, India, 2009. .............................................................. 23

Table 3. Land ownership size, Andhra Pradesh and Madhya Pradesh, India, 2009.................. 30

Table 4. Trees per acre planted by farmers, Andhra Pradesh and Madhya Pradesh, India, 2009.

Table 5. Rotation age selected by farmer, Andhra Pradesh and Madhya Pradesh, India, 2009.. 32

Table 6. Species used in intercropping by farmers in Andhra Pradesh and Madhya Pradesh, India, 2009

Table 7.Cost of farming practices (\$/acre), Andhra Pradesh and Madhya Pradesh, India, 2009. 43

Table 8. Revenue values for farming practices (\$/acre), Andhra Pradesh and Madhya Pradesh, India, 2009

Table 9.Eucalyptus yield and price values, Andhra Pradesh and Madhya Pradesh, India, 2009. 45

Table 10. Summary of the results of financial analysis for converting traditional agricultural croplands into agroforestry in Andhra Pradesh and Madhya Pradesh, India, 2009.

Table 11. Summary of the results of financial analysis for converting traditional agricultural croplands into agroforestry including land estimation value in Andhra Pradesh and Madhya Pradesh, India, 2009.

Table 12. Results of regression analysis for the model that examines the factors affecting financial feasibility of converting traditional farms into agroforestry plantation in Andhra Pradesh and Madhya Pradesh, India, 2009. 


\section{Introduction}

In many parts of the world, pulp and paper companies are becoming heavily dependent on private agroforestry schemes. With growing demand for wood fiber and limited commercial land to grow it on, the forest industry is continually turning to private farmers and individuals to contract timber (Saxena, 1992). In India, companies are limited in the amount of land they can own, making large plantations to continually supply a pulp mill impossible. Natural forests as well are under immense pressure, and available timber from them is decreasing with regulatory systems changing. In India, all natural forests have been designated as ecological conservation zones and no commercial timber harvesting is allowed. This has put a strain on companies, which need large supplies of raw material to operate a mill. In order to alleviate this problem, many companies have turned to out-grower schemes to supply wood to the mills. Local farmers now have the opportunity to benefit from company extension and supplies and return to the company an almost guaranteed supply of raw materials.

According to the FAO (2005), nearly sixty percent of the population in India is heavily dependent on agriculture. Most local farmers produce labor intensive crops, such as rice, wheat, soy, etc., that are highly dependent on world markets, and often see sharp fluctuations in prices. A recent trend in agriculture is adding trees to farmers' traditional croplands. In these agroforestry systems, farmers typically select fast growing tree species that can be harvested after only a few years and mix these with agricultural crops (Arnold, 1987). Other farmers are converting all of their traditional cropland to forests due to difficult crop markets or incentives from forest products corporations (Bertomeu, 2003; Ceccon, 2005). 
Converting all or some of a farmer's cropland to forestry has many potential benefits. This venture could provide increased income, environmental benefits and symbiotic growth through intercropping for a higher output and realized income (Beer, 1987; Pruchapruth, 1996). Additionally, many of the traditional agriculture crops produced in India have very intensive labor requirements. The low level of labor required with most farm forestry operations may provide additional time for farmers to concurrently supplement their income from other activities (Arnold, 1987).

While there are many traditional markets for the trees produced by a farmer, new markets are beginning to open up around the world for cellulosic fiber and other wood based products. Farmers must have the tools to assess these new opportunities in order to make informed decisions based on their local conditions and to realize potential increases in income. Investments are typically longer term and require larger amounts of capital than other agricultural options. Careful consideration of the economics of such conversion is important to farmers in order to make informed decisions to convert their farms to forestry use. Since this is a new practice in many regions of the world, there is little data available, especially to farmers, on the social, economic and environmental aspects of these agroforestry systems.

This study investigates commercially promoted agroforestry schemes in two states in India. The objectives of the study are: (1) to evaluate the financial feasibility of agroforestry techniques employed by farmers in Andhra Pradesh and Madhya Pradesh, India; and (2) to examine factors affecting the financial feasibility of agroforestry schemes in these regions. 


\section{Literature Review}

India is a country heavily dependent on agriculture; nearly sixty percent of the population is involved in farming in India (FAO, 2005). Most local farmers produce labor intensive crops, such as rice, wheat, soy, etc. that are highly dependent on world markets, and often see sharp fluctuations in prices. Shifting land between crops that are more profitable has been practiced for centuries. A recent trend in agriculture is adding trees to the traditional croplands. This system is called agroforestry. In this system, farmers typically select fast growing tree species that can be harvested after only a few years and mix these with agricultural crops. Other farmers are converting all of their traditional cropland to forests due to difficult agricultural crop markets or better incentives from forest products corporations.

The recent increase in demand for timber, fuel wood and pulp wood has influenced farmers to convert their agricultural land to farm forestry. As the size of land holdings continue to decline in many countries, income is increasingly sought from off farm employment. With less on-farm labor, a resulting reduction in annual crop cultivation usually occurs and tree crops that require relatively low labor inputs, begin to gain favor (Arnold, 1987; Stoler, 1978).

Converting all or some of a farmer's cropland to forestry has many potential benefits ranging from increased income, environmental health, and mutually beneficial growth of all crops through intercropping that can result in even higher realized incomes (Beer, 1987;

Pruchapruth, 1996). While farmers have traditionally marketed any trees grown on their property as poles, construction timbers, scaffolding material, and other products, new opportunities are beginning to develop both locally and globally for their wood fiber. Farmers now have improved 
access to new industries including pulp and paper, biofuels, engineered wood products, furniture, and flooring products.

\section{Agroforestry}

"Agroforestry is a collective name for land-use systems and technologies where woody perennials (trees, shrubs, palms, etc.) are deliberately used on the same land-management units as agricultural crops and/or animals, in some form of spatial arrangement or temporal sequence. In agroforestry systems there are both ecological and economic interactions between the different components (Lundgren and Raintree, 1982)." This implies that agroforestry involves at least two species of plants, or plants and animals, one of which is a woody perennial, the system has two or more outputs, lasts more than one year and is inherently more complex than a mono-cropping system (Nair, 1993).

There are different agroforestry systems throughout the world, but they are found more often in the tropical and subtropical regions than in temperate regions (Long and Nair, 1999). This is due in part to the wide variety of plants and socioeconomic situations of these regions, which require a more integrated land use system (Long and Nair, 1999). Typically, agroforestry systems are categorized based on their structural, functional, socioeconomic or ecological basis (Nair, 1993). It is common to use all of these broad classifications in describing one system of agroforestry, as they are highly interrelated. The structural classification, or composition of the components, is broken down into three main categories and is the basis for naming of agroforestry systems: 1.) agrosilviculture involves growing trees with other crops; 2.) silvopastoral, involves growing trees combined with pasture land; and 3.) agrosilvopastoral involves trees, crops and animals on the same land. 
Several factors have contributed to the rising interest in agroforestry: the deteriorating economic situation in many parts of the world, increased tropical deforestation, degradation and scarcity of land because of population pressures, growing interest in farming systems, intercropping and the protection of the environment (Nair, 1993). A 2005 FAO report on the state of the world's forests, claims that studies of the environmental benefits of agroforestry are far fewer than those related to economic benefits, and studies seeking to monetize such benefits are almost non-existent. However, available information indicates that agroforestry can provide a greater range of environmental benefits than conventional types of annual crop cultivation (FAO, 2005). Most research on agroforestry has been conducted from the biophysical perspective, but socio-economic aspects are gaining attention (Mercer and Miller, 1998).

Recently, there has been such a high global demand for timber, fuel wood and pulp wood that one of the best alternatives for agricultural land is to convert into farm forestry. As the size of land holdings continues to decline in many countries, income is increasingly sought from off farm employment. This trend leads to a reduction in cultivation of annuals in order to release labor and trees, requiring low labor inputs, begin to gain favor (Arnold, 1987 ;Stoler, 1978).

In several countries, very successful agroforestry projects are increasing the rate of reforestation and supplying timber, fodder, fruit and fuelwood (Swaminathan, 1987). In the Gujarat State of India, the forestry department started a project in the early 1970's that was accepted by farmers because it was less labor intensive and labor requirements were spread over the year. In the Philippines, an industry-led agroforestry system has also become popular (Swaminathan, 1987). The Paper Industries Corporation of the Philippines project recommended $20 \%$ of the land be used to raise agricultural crops and $80 \%$ be used for tree farming with a fast growing tree for paper pulp, on an eight year rotation (Swaminathan, 1987; Veracion, 1983). The 
project provided farmers with a continuous source of food and income, met the pulpwood needs of the corporation, curbed deforestation and increased the small farmer's income (Swaminathan, 1987).

The role of agroforestry in meeting either present or future requirements of fuelwood, food, fodder and small timber and for environmental protection has been very well recognized in the Indian subcontinent. What is now required is the development of location-specific, needoriented systems along with the necessary support systems so that farmers can get the required seedlings and other inputs easily and market the produce at competitive prices (Singh, 1987). Agroforestry presents an excellent opportunity for low input socio-economic situations as it provides for the integration of various production factors for achieving need based goals, such as fodder and fuel, shelterbelts, ground cover, or cash crops, trees can play a role and be integrated with the existing agricultural production system.

\section{Advantages and Disadvantages of Agroforestry}

Some of the many problems with converting cropland to forestry are marketability, little understanding of the market, little knowledge of forestry and, lack of water (Jain, 1988). There are also some serious costs or constraints to agroforestry. Some of these are reducing the output of staple food crops where trees compete for use of land or depress crop yields through shade, root competition or allelopathic interactions. The incompatibility of trees with agricultural practices such as free grazing, burning, etc., can make it difficult to grow trees. Where the planting season is very restricted, demands on available labor for crop establishment may prevent tree planting or harvesting. Relatively long production period of trees delays returns beyond what may be realistic for poor farmers and increase the risks to them associated with tenure security (Arnold, 1987). 
Some advantages of agroforestry systems are maintaining or increasing site productivity through nutrient recycling and soil protection, at low capital and labor costs; and increased value of output on a given area of land through spatial or inter-temporal intercropping of tree and other plant species. Diversification of the range of outputs from a given area can increase selfsufficiency and/or reduce the risk to income from adverse climatic, biological or market impacts on particular crops. Spreading the need for labor inputs more evenly seasonally may reduce the effects of sharp peaks and troughs in activity characteristic of tropical agriculture. Agroforestry may provide productive applications for underutilized land, labor or capital and creating capital stocks available to meet intermittent costs or unforeseen problems (Arnold, 1987).

Agroforestry systems have the potential to improve the economic, environmental and social situation, or the 'triple bottom line' of the farmers involved. A typical agroforestry system allows mutually beneficial economic and ecological interactions between the woody and non woody components to increase, sustain and diversify the total land output along with farming systems that incorporate perennial trees and shrubs that have the advantage of producing fuelwood, fruit, fodder and other products along with the annual crops (Swaminathan, 1987). In addition, well designed systems can decrease the farmer's exposure to seasonal environmental variations and maintain and improve soil health (Swaminathan, 1987). The use of agroforestry systems can improve soil through stabilization from the roots increased soil resistance to erosion by maintaining organic matter (Long and Nair, 1999). The tree canopy can provide shade, reducing evaporation and leaf litter fall acts as a mulch bringing nutrients to the surface and reducing evaporation and erosion (Schroeder, 1993).

A study in Tanzania showed that farmers using agroforestry methods earned twice as much of the annual income and 13 times the net income compared to traditional practices 
(Reyes, 2008). This study found that grevillea grown with cardamom improved the growth parameters of grevillea and that intercropping did not significantly affect the growth of grevillea for the first six years. Black pepper, in this study, grew the best when intercropped with grevillea, compared to other trees and natural forest planting. This study also showed that the agroforestry systems improved the soil, mainly through nitrogen and organic matter and produced ideal solar levels for the growing of these intercropped plants. A study in Kenya found that in tree-maize intercropping, the trees had no effect on the growth or the nutrient uptake during the first two years (Imo, 2009).

\section{Eucalyptus as a Tree Crop for Agroforestry}

Rapid increases in the establishment of forest plantation in Asia and the Pacific have been dominated by species of eucalyptus (Ball, 1996). The genus Eucalyptus encompasses over 700 species, most of which occur naturally in Australia and can produce essential oils, leaf-meal, chemicals, honey, firewood, raw material for pulp, poles, etc. (Kashio, 1996). Industrial planting of eucalyptus has increased, especially to produce the raw material for pulp and paper manufacturing. Eucalyptus pulp from intensively managed plantations is currently less costly than that produced from other hardwoods, and is taking a large part of the pulp market, even displacing softwood pulp on world markets (Davidson, 1996).

There is a long history of debate whether or not eucalyptus can or should be used as an agroforestry species. Some have noted the high uptake of water and nutrients and the belief that some species have negative chemical effects on other species as reasons why eucalyptus cannot be planted in agroforestry systems (Sungsumarn, 1996; Patil, 1996; Raintree, 1996). The debate is frequently framed in terms of benefits and negative aspects ecologically, when the major problem actually relates to land availability, tenure and management (Turnbull, 1999). In 
addition, many of these "myths" of eucalyptus have been proven untrue through scientific research and field observations (Patil, 1996; White, 1996).

Over 13 million hectares of eucalyptus were estimated, in 1996, to be in plantations worldwide (Davidson, 1996). India alone in 1996, had 4.8 million hectares of eucalyptus plantations, adding up to 25 percent of their total plantation area (Davidson, 1996). Tree farming with eucalyptus has now become so popular that irrigated and fertilized fields are also being used for this purpose (Swaminathan, 1987; CSE, 1985). Similar success has been achieved in Haiti, Kenya, Senegal and Nepal (Swaminathan, 1987; WRI, 1985).

Eucalyptus was introduced to India in the mid 1800s to meet firewood demands (Palanna, 1996). One hundred seventy species of eucalyptus have been tried in India, with the favorite being a hybrid of E. tereticornis, along with other species such as E. grandis, E. citirodora, E. globulus and E. camaldulensis In many cases, including India, the pulp and paper manufacturers have developed their own specific clones for increased advantages such as faster growth, disease resistance and better fiber quality.

There has been much debate over the use of eucalyptus in the world. However, research done on eucalyptus appears to show less water use per unit weight of biomass produced than other kinds of trees and many agricultural crops, but their potentially high biomass production under low rainfall could potentially impact stream flow and ground water quantities more than slower growing plants or trees (Davidson, 1996).

\section{Role of Pulp and Paper Industry in Agroforestry}

The pulp and paper industry in India employs 200,000 people directly and indirectly supports 1,000,000 people and is nearly a $\$ 2$ billion a year industry (Lal, 2005). Historically, the 
paper industry in India has grown between 5 and 8 percent annually. As the global and domestic demand for paper products increases, a large strain is placed on finding and procuring the supply of wood fiber for processing. Under this situation, many pulp and paper manufacturers have turned to cloning new hybrid tree species, particularly with those from the Eucalyptus family. With identical genotypes that are selected for desirable attributes, new clones reduce growing time, are better suited to the region, produce higher quality fiber, have a high rate of survival, and have a much higher productivity than seed-based planting where seeds are generally gathered from either open, or at best, controlled pollinated sources (Lal, 1996). These new advances have helped improve pulp and paper plant productivity, thus lowering the cost per unit volume of paper product.

As one of the leading pulp and paper companies in India, the Indian Tobacco Corporation, Limited, (ITC) works very closely with private farmers to grow the trees required for their mills. ITC estimates the amount of wood needed will nearly triple between 2007 and 2010. This increase will require many thousands of hectares to be planted in plantations and in land converted from agriculture into farm forestry. In 2005, approximately 12,400 hectares were planted in cooperation with ITC and they estimated that by 200827,000 hectares would be planted and 100,000 by 2010. ITC, which promises buy-back of all timber, claims that traditional agriculture leads to profits between 300 dollars/hectare/year and 500 dollars/ha/yr. whereas the average net income by farmers using their clonal plantings is between 600 dollars/ha/yr and 1,000 dollars/ha/yr (ITC, 2008).

\section{Financial Feasibility of Agroforestry}

Studies on financial feasibility of agroforestry are not abundant and use many different analysis tools. Calculations such as net present value (NPV), internal rate of return (IRR), 
benefit-cost ratio (BCR) and Land Equivalency Value (LEV) are common methods for evaluating the financial feasibility of agroforestry farms (Nair, 1993; Bertomeu, 2003; Arnold, 1987; Jain and Singh, 2000; Niskanen, 1997).

In cases in India, returns varied and some farmers profited and others would have been better continuing to plant their traditional crops. In case studies done by Jain (1988), one farmer, after six years had a BCR of 1:5, which is considered highly profitable ). Jain (1988) conducted multiple case studies in the Gujarat region of India, researching prices for labor, material inputs, harvesting sales and then calculated cost benefit ratios.

In poplar (Populus deltoides) agroforestry plantations in northern India, Jain and Singh (2000) reported that traditional crops had BCRs ranging from 1.14 to 2.47. The poplar agroforestry schemes in the study had BCRs ranging from 1.01 to 1.35 .

Research done in Thailand by Kongsom and Munn (2002) found that two different planting densities of eucalyptus both had an optimal rotation age of nine years and that after three years, the plantations generated a positive Land Expectation Value (LEV). World Bank annual reports projected that economic rates of return for industrial plantation forestry and agroforestry ranged from 10 to $30 \%$ from 1977 to 1986 , and concluded that agroforestry projects can simultaneously ensure increased farm productivity and income for rural people and protect the farming environment (soil and water) (Spears, 1987).

Given the nearly limitless types of agroforestry practices and the dearth of financial assessments evaluating these practices, agroforestry research has a serious knowledge gap to fill. This gap is partly due to the relatively recent development of agroforestry as a scientific discipline, and the lack of experimental designs specifically applicable to agroforestry systems 
(Steppler, 1987). In India, specifically the states of Andhra Pradesh and Madhya Pradesh where plantations are being established rapidly and extensively, there is a lack of information on site specific agroforestry schemes. Because of the wide variety in the social, environmental and economic situations of world regions and even within regions, site specific examples must be reported to help local farmers. This study examines agroforestry schemes in two states of India, under company promoted situations. It provides specific cost and revenue values, volumes and other data that can be used in agroforestry evaluations for these regions. In addition, demographic and other practices involved in agroforestry have been examined with the intent to aid in an overall understanding of agroforestry in these regions. 


\section{Methods}

\section{Description of Study Sites}

\subsection{Andhra Pradesh}

\section{Location}

The state of Andhra Pradesh is located on the south-east coast of India. It lies between $12^{\circ} 41^{\prime}$ and $22^{\circ} \mathrm{N}$ latitude and $77^{\circ}$ and $84^{\circ} 40^{\prime} \mathrm{E}$ longitude, and is bordered by Maharashtra, Chhattisgarh and Orissa in the north, the Bay of Bengal in the East, Tamil Nadu to the south and Karnataka to the west (Figure 1) (Encyclopedia Britannica, 2009).

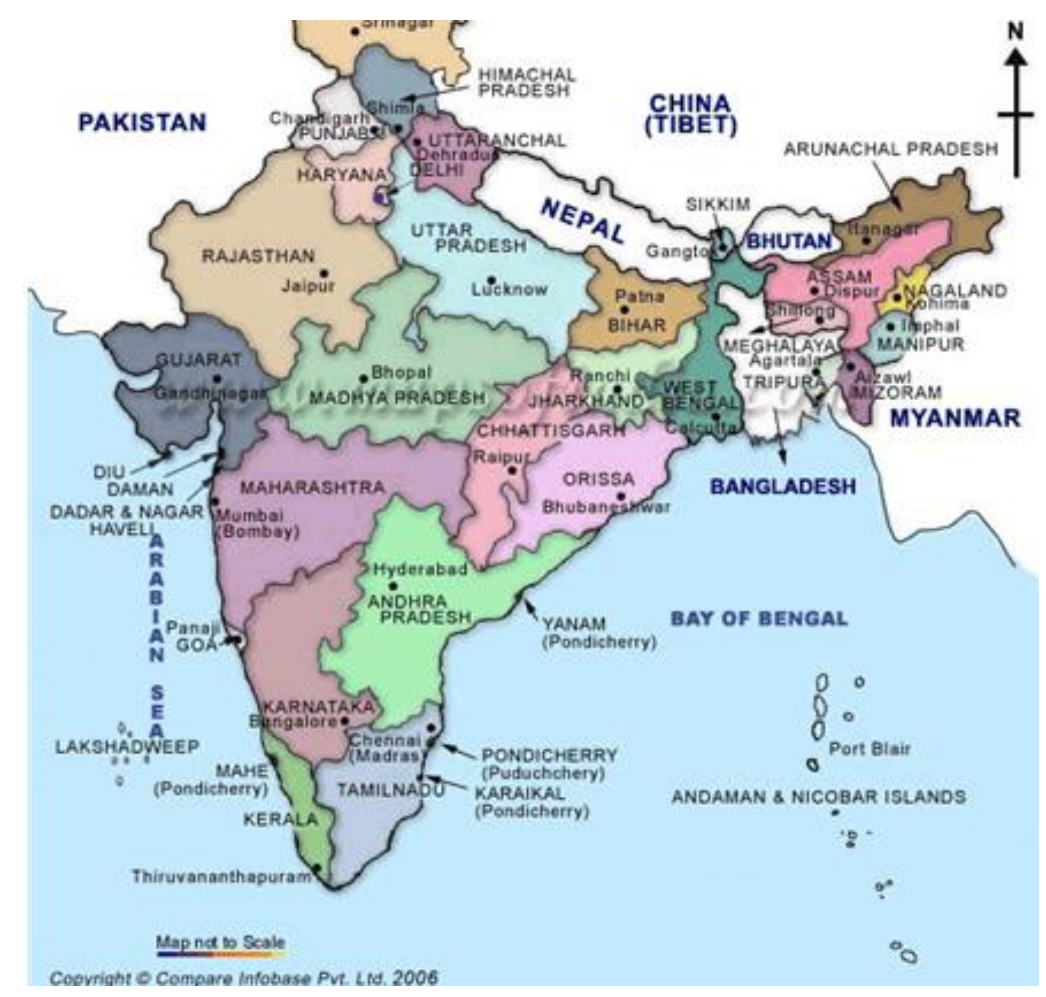

Figure 1. Political Map of India (Maps of India, 2009). 


\section{Climate}

The three seasons of Andhra Pradesh are summer that lasts from March to June, a season of tropical rains from July to September (South West monsoon) (Figure 2), and winter that lasts from October to February (North East monsoon) (Figure 3). Throughout much of the state, annual maximum temperatures range from the mid-70s (Figure 4) to the low 80s F (mid-20s C), and minimum temperatures usually range in the low $50 \mathrm{~s} \mathrm{~F}$ (about 10 to $12{ }^{\circ} \mathrm{C}$ ). On the coastal plain, however, summers are extraordinarily warm, with temperatures often exceeding $100^{\circ} \mathrm{F}$ $\left(38{ }^{\circ} \mathrm{C}\right)$ in some places. Summers are cooler and winters colder on the central plateau. Annual rainfall, which derives largely from the southwest monsoon, varies widely across the state. Some coastal areas may receive as much as 55 inches $(1,400 \mathrm{~mm})$ of rain, while the northern and western parts of the plateau may receive as little as 20 inches $(500 \mathrm{~mm})$ (Figure 5).

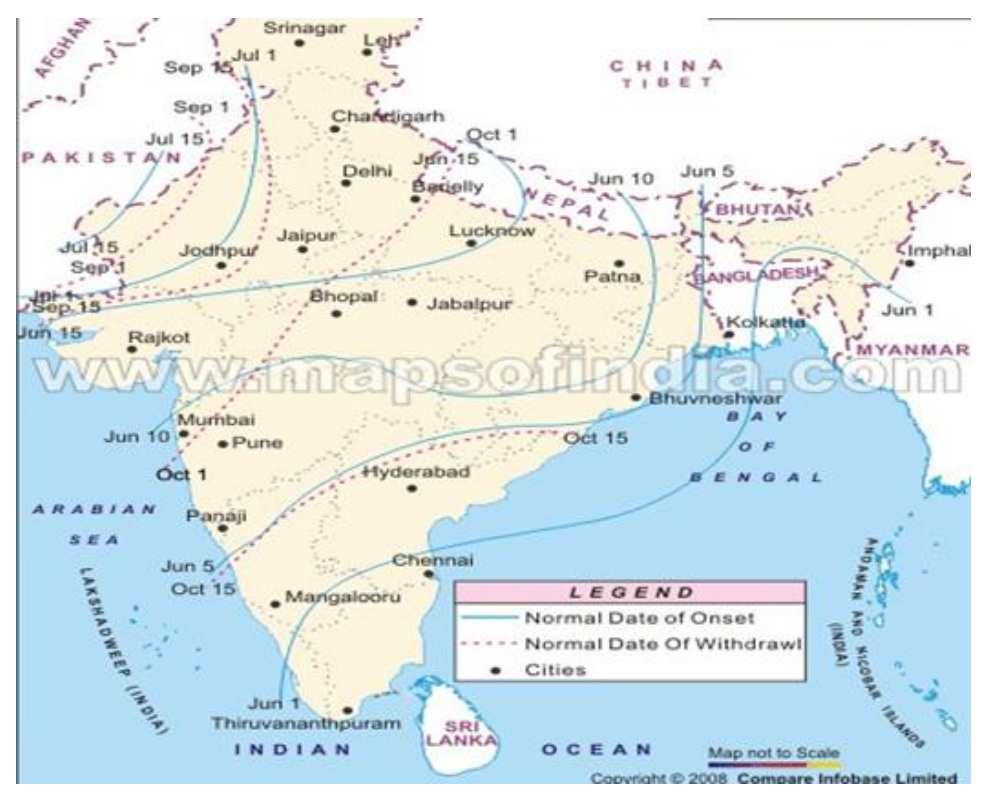

Figure 2. South West Monsoon of India (Maps of India, 2009). 


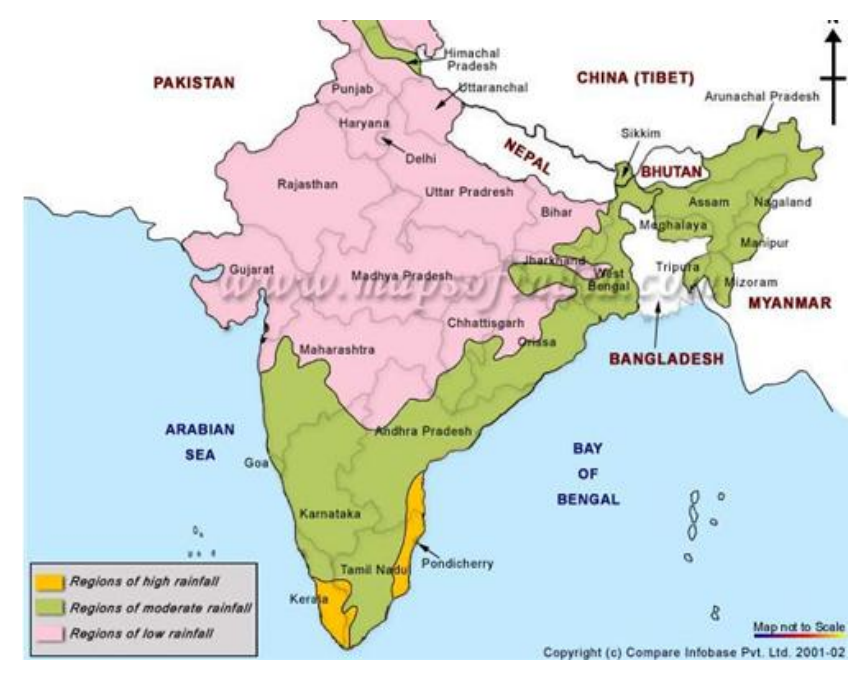

Figure 3. North East Monsoon of India (Maps of India, 2009).

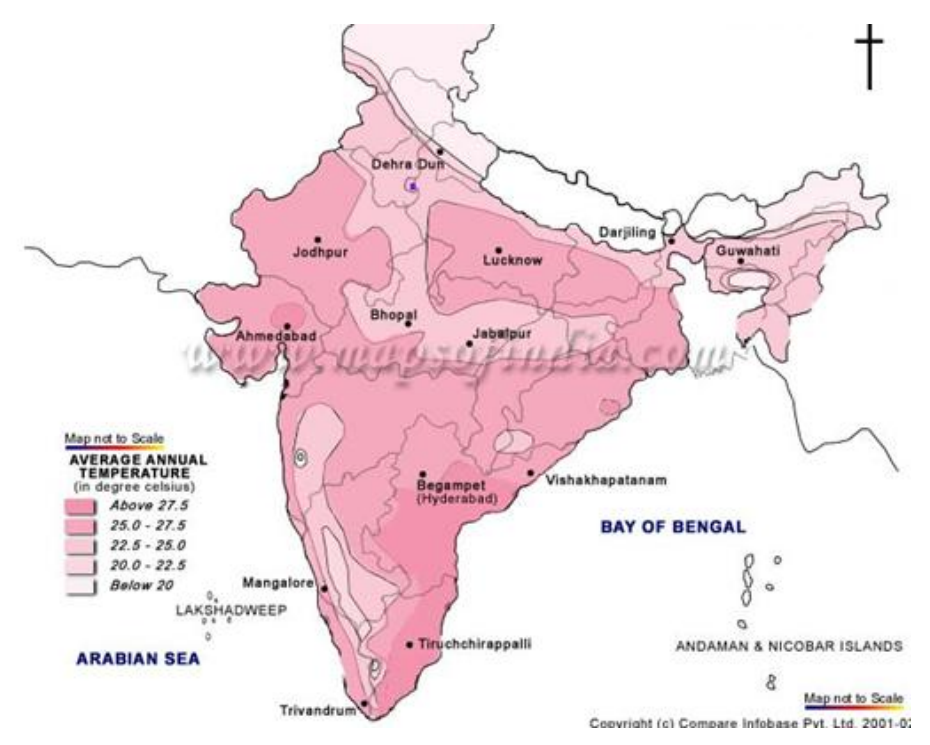

Figure 4. Annual Temperature of India (Maps of India, 2009). 


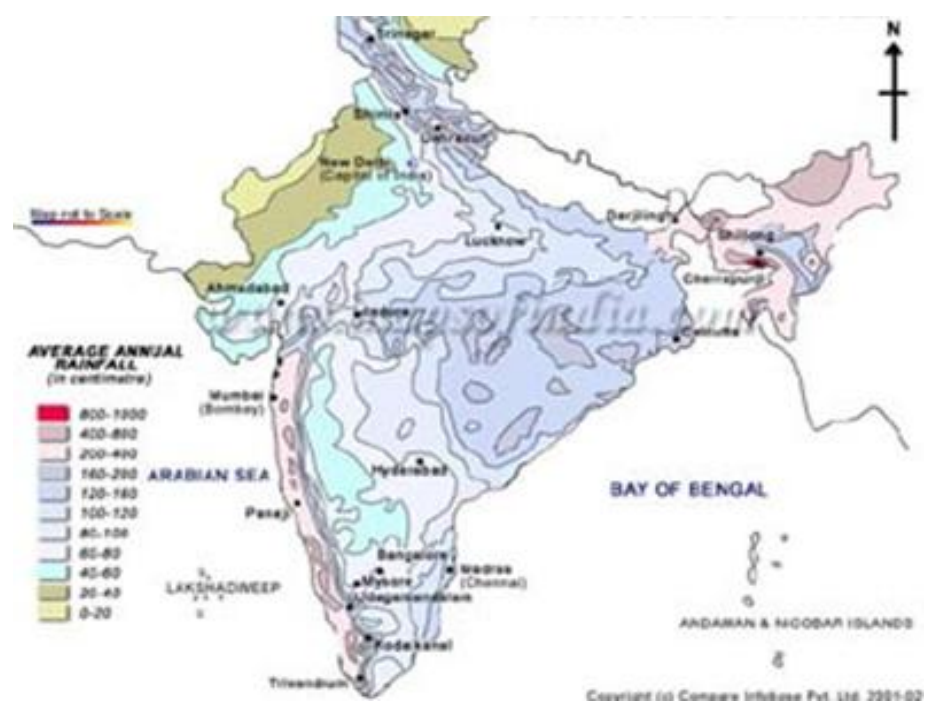

Figure 5. Annual Rainfall (Maps of India, 2009).

\subsection{Madhya Pradesh}

\section{Location}

The state of Madhya Pradesh is located in central India. It lies between $21^{\circ} 04^{\prime} \mathrm{N}$ latitude and $74^{\circ} 02^{\prime}$ and $82^{\circ} 49^{\prime} \mathrm{E}$ longitude, and is bordered by Uttar Pradesh, Chhattisgarh, Maharashtra, Gujarat and Rajasthan (Figure 1) (Encyclopedia Britannica, 2009).

\section{Climate}

The climate in Madhya Pradesh follows the monsoon weather pattern. The seasons are summer which lasts March through May, the rainy months of the southwest monsoon (Figure 2) from June through September and winter from November through February (Figure 3). The summer is hot, dry, and windy. Low temperatures (Figure 4) average in the upper 70s F (about $25^{\circ} \mathrm{C}$ ), while high temperatures typically reach the low $100 \mathrm{~s} \mathrm{~F}$ (about $40{ }^{\circ} \mathrm{C}$ ). Winters are usually dry, with daily temperatures normally rising from about $50^{\circ}$ (about $10^{\circ} \mathrm{C}$ ) into the upper 
70s $\mathrm{F}$ (about $25^{\circ} \mathrm{C}$ ). Temperatures during the monsoon season usually range from the low $70 \mathrm{~s} \mathrm{~F}$ (low 20s C) to the upper 80s F (low 30s C).

The average annual rainfall is about 44 inches $(1,100 \mathrm{~mm})$ (Figure 5). In general, precipitation decreases westward and northward, from 60 inches $(1,500 \mathrm{~mm})$ or more in the east to about 32 inches $(800 \mathrm{~mm})$ in the west. Most parts of Madhya Pradesh receive almost all of their precipitation in the monsoon months.

\section{Site Selection and Study Population}

ITC Bhadrachalam Paperboards Ltd, one of the largest pulp and paper producing companies in India, is a subsidiary company of Indian Tobacco Company (ITC). ITC's mill is located in Sarapaka Village near Bhadrachalam in Khamman District of Andhra Pradesh, India. Two regions were selected for this study: 1.) Andhra Pradesh and 2.) Madhya Pradesh, India. The region of Andhra Pradesh was selected due to a previous visit and introduction to the management of ITC. The two regions were selected due to ITC involvement in these areas and the levels of activity in eucalyptus planting in conjunction with agroforestry practices. The area of Andhra Pradesh has a high number of farmers involved in eucalyptus planting due to the location of the ITC mill. Much of the state is considered to be in the "core zone," or within 250 $\mathrm{km}$, of the mill. The state of Madhya Pradesh has only recently begun planting of eucalyptus. ITC has expanded its distribution to this region for two main reasons. First the company was interested in developing another mill location, possibly in this state. Also, there is intense competition for the wood product being developed by the farmers. In order to reduce the competition, and therefore ensure more wood coming into the mill, the company has helped to develop the plantations in this area. Farmers from within the state of Andhra Pradesh were 
selling their wood as pole wood in the state of Madhya Pradesh in order to capitalize on higher prices. According to one source, the company decided that in order to reduce the loss of pulpwood resources in this manner, it would be beneficial to develop plantations in Madhya Pradesh to out-compete the farmers in Andhra Pradesh and therefore those farmers would again sell their wood to the mill as pulpwood.

Thirty six farmer fields in the core zone surrounding the mill and eleven fields in the Madhya Pradesh state were selected for analysis. The individual fields were selected based on availability of farmers to interview, company contacts and willingness of the farmers to cooperate and, most importantly, the activities the farmers were carrying out in the fields. Farmers who were engaged in agroforestry were targeted to contact. Farmers interviewed in the study were recommended by company personnel.

\section{Data Collection}

Personal interviews were carried out to collect the data for the study. These interviews were necessary due to the absence of available information and the rural nature of the area. Most costs incurred by the farmers can fluctuate between villages and even between neighboring individuals so it was necessary to interview as many as possible.

Farmers were interviewed on their farms or in their households. Since most of the farmers planting eucalyptus through ITC were not engaged in agroforestry, the first task was to identify those farmers who were involved in agroforestry. This was done with the help of ITC staff.

A cross-sectional study method was followed for these interviews, in which a subset of a larger population is observed, all in the same time period. Cross sectional studies take a slice of 
an overall population and study them, in order to base findings on the overall population. A predesigned survey (See Appendix B) was created prior to collecting data, although the actual interviews did not strictly follow the survey draft. The survey was based on predetermined questions and through the course of the interviews some questions were found to be unnecessary and additional questions needed to be added.

Farmers were interviewed about the activities occurring on their farms. Demographic information (education, gender) was collected in order to gain an understanding of the population. Information on land ownership size was gathered to test whether only large or small landowners participated in agroforestry or if there were any differences between land ownership sizes between regions. Information on farming practices for intercrops and trees (rotation age, fertilization, etc.) was collected to better understand the timing of activities on the farms. Costs and revenues associated with these practices were also collected to use in financial analysis. Eucalyptus yields and prices were gathered to use in the financial analysis and for evaluation between regions. All data were taken on a per acre basis.

\section{Analysis}

Summary statistics were calculated for the data collected from the survey. T-Test and Chi-squared tests were conducted to compare means and distributions between the two regions with respect to demographic variables, cost and revenue variable.

To examine the economic feasibility of converting traditional agricultural lands to agroforestry or farm forestry, standard financial criteria were calculated. Specifically, Net Present Value (NPV), Benefit-Cost Ratio (BCR), Internal Rate of Return (IRR), Equivalent Annual Income (EAI) and Land Equivalency Value (LEV) were calculated. A discount rate of 
$12 \%$ was used for the analysis. In addition, a sensitivity analysis was conducted by using other discount rates, specifically 6,12 and $15 \%$. These higher discount rates were used in the economic analysis because the study was conducted in a developing country where poorer farmers are less able to delay consumption and have a higher time preference (Schroeder, 1993)

The NPV formula of NPV $=\Sigma \frac{B-C}{(1+i)^{n}}$ was used where B is present value of benefits, $\mathrm{C}$ is present value of costs, $\mathrm{i}$ is the discount rate used and $\mathrm{n}$ is the period of time. Net present value accounts for the annual costs and benefits over the lifespan of a project and discounts them at a preselected rate. These discounted costs and benefits are summed as a single indicator of a projects long term value, estimated at time of implementation (Nair, 1993). A project that returns a NPV value greater than zero is feasible, meaning that the benefits are greater than the costs.

The benefit-cost ratio of $\Sigma \frac{B}{C}$ was used where B is present value of benefits and $\mathrm{C}$ is present value of costs. If the ratio of benefits to costs is greater than one, the project will have a positive net return. The greater the ratio of benefits to costs, the more attractive the return (Nair, 1993).

Internal rate of return (IRR) is calculated as $\Sigma \frac{(B-C)}{(1+p)^{t}}=0$ where $B$ is present value of benefits, $\mathrm{C}$ is present value of costs, $\mathrm{p}$ is internal rate of return and $\mathrm{t}$ is time period. IRR is theoretically the maximum rate of interest that a project can repay while recovering all investment costs (Nair, 1993). In calculation, IRR is the discount rate that makes NPV equal to zero. 
Equivalent annual income is $\quad \mathrm{EAI}=\mathrm{NPV} \frac{i(1+i)^{n}}{(1+i)^{n}-1}$ where NPV is the calculated net present value, $\mathrm{i}$ is the discount rate and $\mathrm{n}$ is the time period. EAI is the annual equivalent of the net present value over the project period.

Land Equivalency Value (LEV) is $\frac{\text { Net Value in Year } n}{(1+i)^{n}-1}$ where $\mathrm{i}$ is the interest rate and $\mathrm{n}$ is the rotation age in years. LEV estimates the value of bare land used for growing timber, with timber production assumed for an infinite series of identical rotations or cutting cycles (Straka and Bullard, 1996). After LEV was calculated, it was added into the system and the other analysis were recalculated.

The schedule of activities assumed for a rotation was based on the recommended practices by ITC. Mean values for the activities were used from farmer responses collected from the survey (Table 1). Company estimates for pulp yield were used for both regions. 
Table 1. Cost and revenue estimates used in evaluating financial feasibility of converting traditional croplands into agroforestry in Andhra Pradesh and Madhya Pradesh, India, 2009.

\begin{tabular}{|c|c|c|c|c|}
\hline \multirow{2}{*}{ Activity } & \multicolumn{2}{|c|}{ Region 1 } & \multicolumn{2}{c|}{ Region 2 } \\
\cline { 2 - 5 } Intercrop Planting & Value (\$/acre) & Year & $\$ 99.40$ & Vear \\
& \multirow{2}{*}{$\$ 219.80$} & 1 & $\$ 106.00$ & 1 \\
& & & $\$ 78.50$ & 2 \\
& & & $\$ 158.90$ & 3 \\
\hline \multirow{3}{*}{ Intercrop Harvesting } & $\$ 367.10$ & 1 & $\$ 379.80$ & 2 \\
& & & $\$ 260.40$ & 3 \\
\hline Eucalyptus Planting & $\$ 31.90$ & 1 & $\$ 51.70$ & 4 \\
\hline Plowing & $\$ 25.80$ & $1,2,3,4$ & $\$ 0$ & None \\
\hline Cultivation & $\$ 12.5$ & $1,2,3,4$ & $\$ 0$ & None \\
\hline Fertilizer & $\$ 20.70$ & $1,2,3,4$ & $\$ 0$ & None \\
\hline Irrigation & $\$ 32.80$ & $1,2,3,4$ & $\$ 0$ & None \\
\hline Farm Yard Manure & $\$ 12.50$ & $1,2,3,4$ & $\$ 0$ & None \\
\hline Insecticide & $\$ 16.70$ & 1 & $\$ 0$ & 4 \\
\hline Eucalyptus Harvest & $\$ 1,185.75$ & 4 & $\$ 3,361.70$ & \multirow{2}{*}{} \\
Revenue & & & & \\
\hline
\end{tabular}

Regression analysis was carried out to understand how Net Present Value (NPV), the dependant variable, changes when the independent variables vary (Table 2). NPV, the dependant variable, is based on the discounted values of the costs and revenues of the system. 
Table2: Description of the variables used in the regression model that examines the factors affecting financial feasibility of converting traditional farms into agroforestry plantation in Andhra Pradesh and Madhya Pradesh, India, 2009.

\begin{tabular}{|c|c|}
\hline Variables & Definition and Description \\
\hline \multicolumn{2}{|c|}{ Dependent Variable } \\
\hline NPV & $\begin{array}{l}\text { Net Present value of agroforestry plantation (\$/acre) using a } 12 \% \text { discount } \\
\text { rate. }\end{array}$ \\
\hline \multicolumn{2}{|c|}{ Independent Variables } \\
\hline EDUC & $\begin{array}{l}\text { Highest educational attainment of the respondent. } 1=\text { No education; } 2= \\
\text { Grades } 1-4 ; 3=\text { Grades } 5-8 ; 4=\text { Grades } 9-12 ; 5=\text { Above Grade } 12\end{array}$ \\
\hline GENDER & Gender of the respondent. $0=$ Male; $1=$ Female \\
\hline ACRES & Size of the agroforestry farm in acres. \\
\hline REGION & Location of agroforestry farm. $0=$ Andhra Pradesh; $1=$ Madhya Pradesh \\
\hline START & $\begin{array}{l}\text { Year of conversion to agroforestry farm. } 1=2008 ; 2=2007 ; 3=2006 ; 4= \\
2005 ; 5=2004 ; 6=2003 ; 7=2002 ; 8=2001 ; 9=2000 ; 10=1991\end{array}$ \\
\hline SPACE & $\begin{array}{l}\text { Spacing use in plantation; } 1=3 \mathrm{X} 1 \mathrm{X} 1 \mathrm{~m} ; 2=9 \mathrm{X} 4.5 \mathrm{ft} ; 3=3 \mathrm{X} 1.5 \mathrm{~m} ; 4=3 \mathrm{X} 2 \mathrm{~m} \text {; } \\
5=8 \mathrm{X} 1 \mathrm{X} 1 \mathrm{~m}\end{array}$ \\
\hline TPA & Trees per acre used in plantation \\
\hline INTERCROP & Number of agricultural intercrops used \\
\hline COTTON & Type of intercrops used. $0=$ other agricultural crops; $1=$ cotton \\
\hline PLOW & Plowing cost in \$/acre \\
\hline CULTIVATE & Cultivation cost in $\$ /$ acre \\
\hline FERTILIZE & Fertilization cost in $\$ /$ acre \\
\hline IRRIGATE & Irrigation Cost in $\$ /$ acre \\
\hline INTERCOST & Cost of intercrops in \$/acre \\
\hline PLANTCOST & Eucalyptus planting cost in \$/acre \\
\hline INTEREV & Revenue from intercrops in \$/acre \\
\hline PLANTREV & Eucalyptus revenue in \$/acre \\
\hline
\end{tabular}

Five categories of independent variables were included in the model: 1.) farmer characteristics; 2.) farm characteristics; 3.) types of farm practices; 4.) costs of farm practices; and 5.) revenues from farm products. Farmer characteristics are represented by the variables EDUC and GENDER. It is hypothesized that EDUC will have a positive influence on NPV. Nkonya et al. (2004) suggest that higher education levels of farmers influences household income strategy, land management practices and labor use in crop production in Uganda. In the 
Sudan, it was found that adoption of new technologies increased with higher education levels of the farmers (Glover, 2005). Based on these studies, it is hypothesized that education should positively influence NPV. GENDER will have a positive influence on NPV because in this society, males are more dominant in the farming community and typically have more experience in farming. This experience should lead to more knowledge of farming, and therefore higher NPVs. Farm characteristics are represented by the variables ACRES and REGION. It is hypothesized that both of these variables will have a positive influence on NPV because more commercial minded farmers tend to have larger acreages and would therefore be willing to put more inputs into the system and aim to receive maximum revenue. The REGION variable should be positive because of regional differences in value due to product favoring Madhya Pradesh. Types of farm practices are represented by the variables START, SPACE, TPA, INTERCROP, and COTTON. It is hypothesized that START would have a negative influence on NPV because more recent years should have higher quality tree clones and can benefit from advancements the company has made, or mistakes that have been learned from earlier farmers. It is hypothesized that SPACE and TPA would have a positive influence because the higher values relate to more trees, and therefore raw material, per acre. It is hypothesized that INTERCROP would have a positive influence because the higher number of intercrops planted should lead to a higher income. It is hypothesized that using cotton as an intercrop would have a positive influence on NPV because many farmers planted this species as an intercrop did so because they believed it had high commercial value. The costs variables are represented by PLOW, CULTIVATE, FERTILIZE IRRIGATE, INTERCOST, and PLANTCOST. Since these variables are all costs, they would most likely have a negative impact on the NPV. The revenues are represented by 
INTEREV and PLANTREV and are expected to be positively related to NPV since these are income to the farmer. 


\section{Results}

\section{Personal Interview Response}

More than 80 farmers were initially contacted to be interviewed. Due to time constraints and scheduling difficulties only 60 farmers were interviewed for the study: 11 farmers in Madhya Pradesh and 49 in Andhra Pradesh. However, due to irregularities in some of the data, only 36 were used. Farmers were interviewed through a translator who was an ITC employee, unless the farmer spoke English. Field notes were taken during interviews to be analyzed.

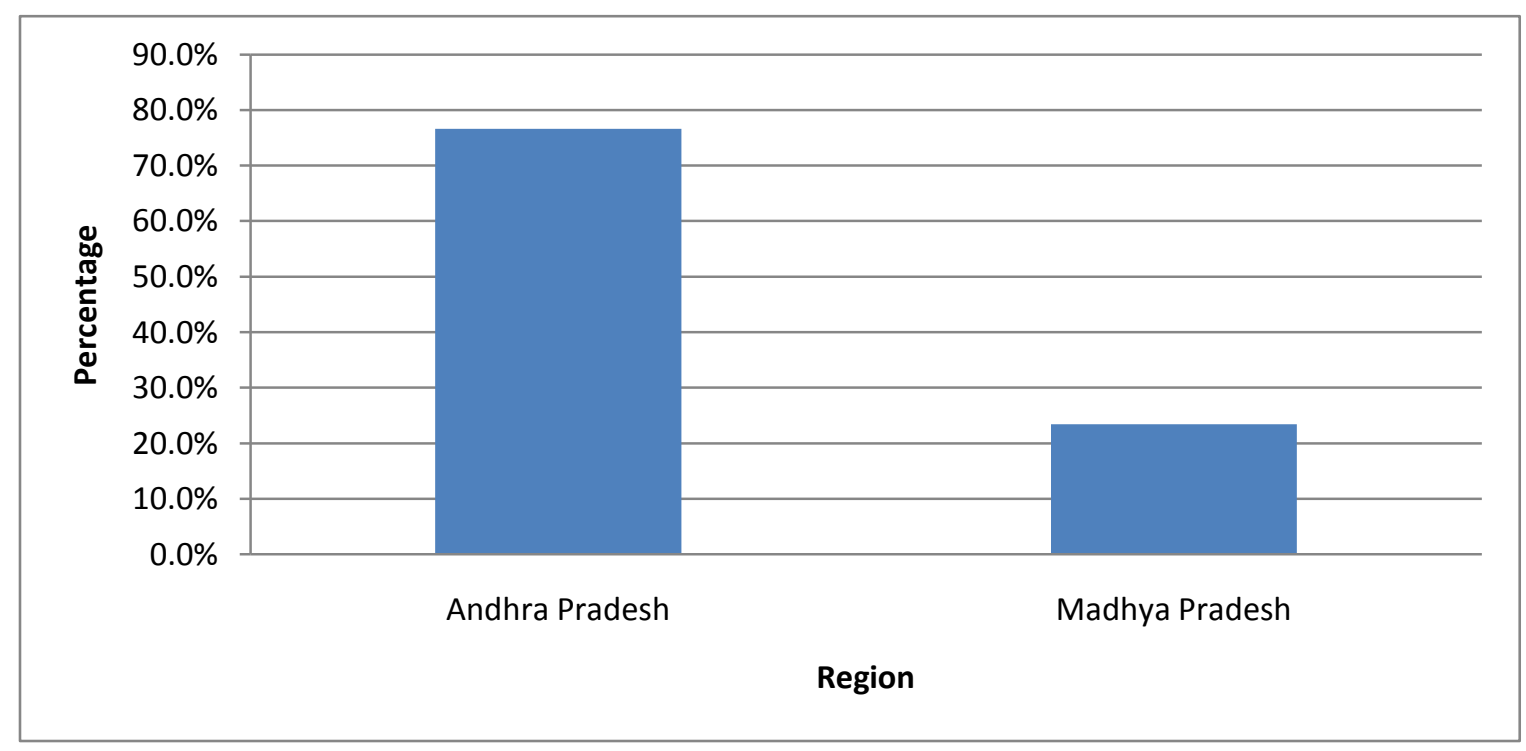

Figure 6. Distribution of farmer by region, Andhra Pradesh and Madhya Pradesh, India, 2009.

Andhra Pradesh had more farmers interviewed for the study (Figure 6). The number of farmers in this region is much greater than in region 2, Madhya Pradesh. Distribution of farmers by village is presented in Figure 7. 


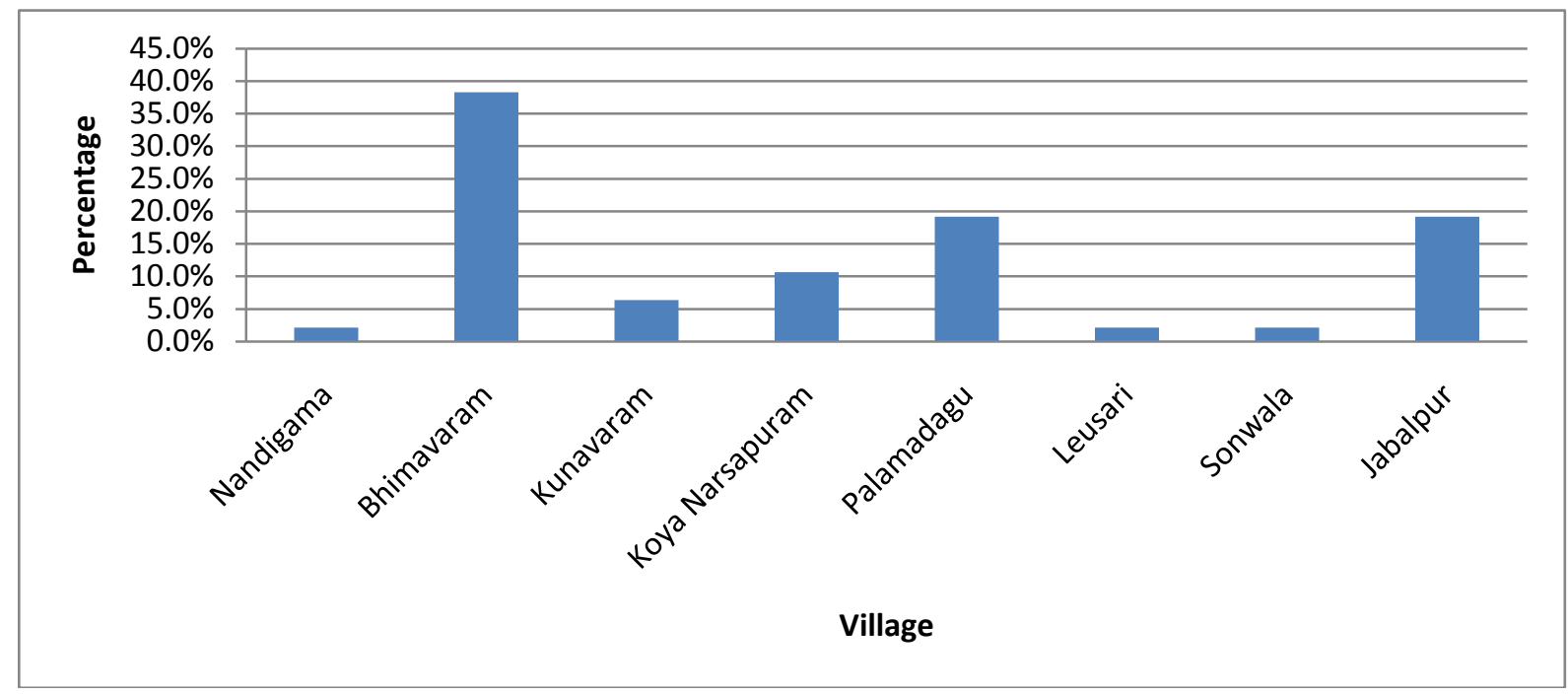

Figure 7. Distribution of farmer by village, Andhra Pradesh and Madhya Pradesh, India, 2009.

\section{Demographic Characteristics of Farmers Interviewed}

Overall, most of farmers (40\%) interviewed received no formal education (Figure 8).

This is not surprising since most farmers involved in agriculture in India are rural, poorly

educated subsistence farmers. Tribal farmers also make up a significant proportion of the farmers in India. These individuals are often isolated from larger villages where schools are available, and have neither the money nor the means to go to school. 


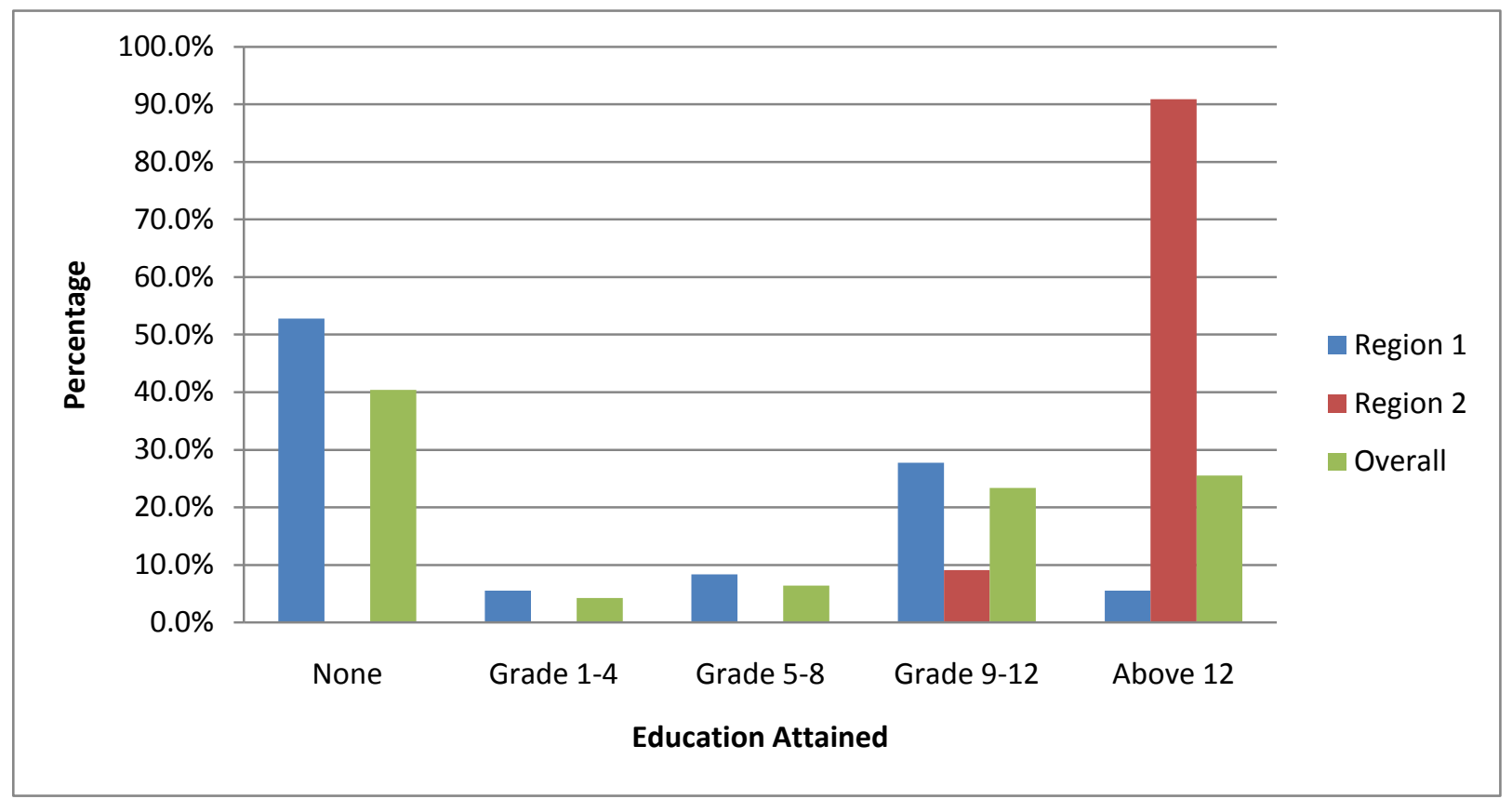

Figure 8. Distribution of farmer by education, Andhra Pradesh and Madhya Pradesh, India, 2009. *Statistically significant at .05 level using Chi-Square test.

In region $1,52 \%$ of the interviewees had no formal education. Again, this is not surprising given the characteristics of the farmers in this region. Many of the farmers in this region are concentrated around the company mill. The area is very rural and is a major agricultural production region. The next highest percentage was in the grade 9-12 group, with $27.8 \%$. This group is mainly the farmers closest to the mill town, where there are more opportunities for education. The farmers in region 2 were extremely well educated. Over $90 \%$ had an education above grade 12 , and the remaining $9 \%$ had an education in the grade $9-12$ group. The education of farmers between the two regions was significantly different $\left(\mathrm{X}^{2}\right.$ $=32.632, \mathrm{p}$ value $=1.42089 \mathrm{E}-06)$.

The gender distribution is heavily weighted towards males. Overall, $87.2 \%$ of the farmers interviewed were males (Figure 9). Only Region 1 had female farmers represented in the sample. In this region, $83.3 \%$ of the farmers interviewed were males and $16.7 \%$ were females. The 
distribution of farmers by gender was not significantly different $\left(\mathrm{X}^{2}=2.102, \mathrm{p}\right.$ value $=$ 0.147143 ) between 2 regions.

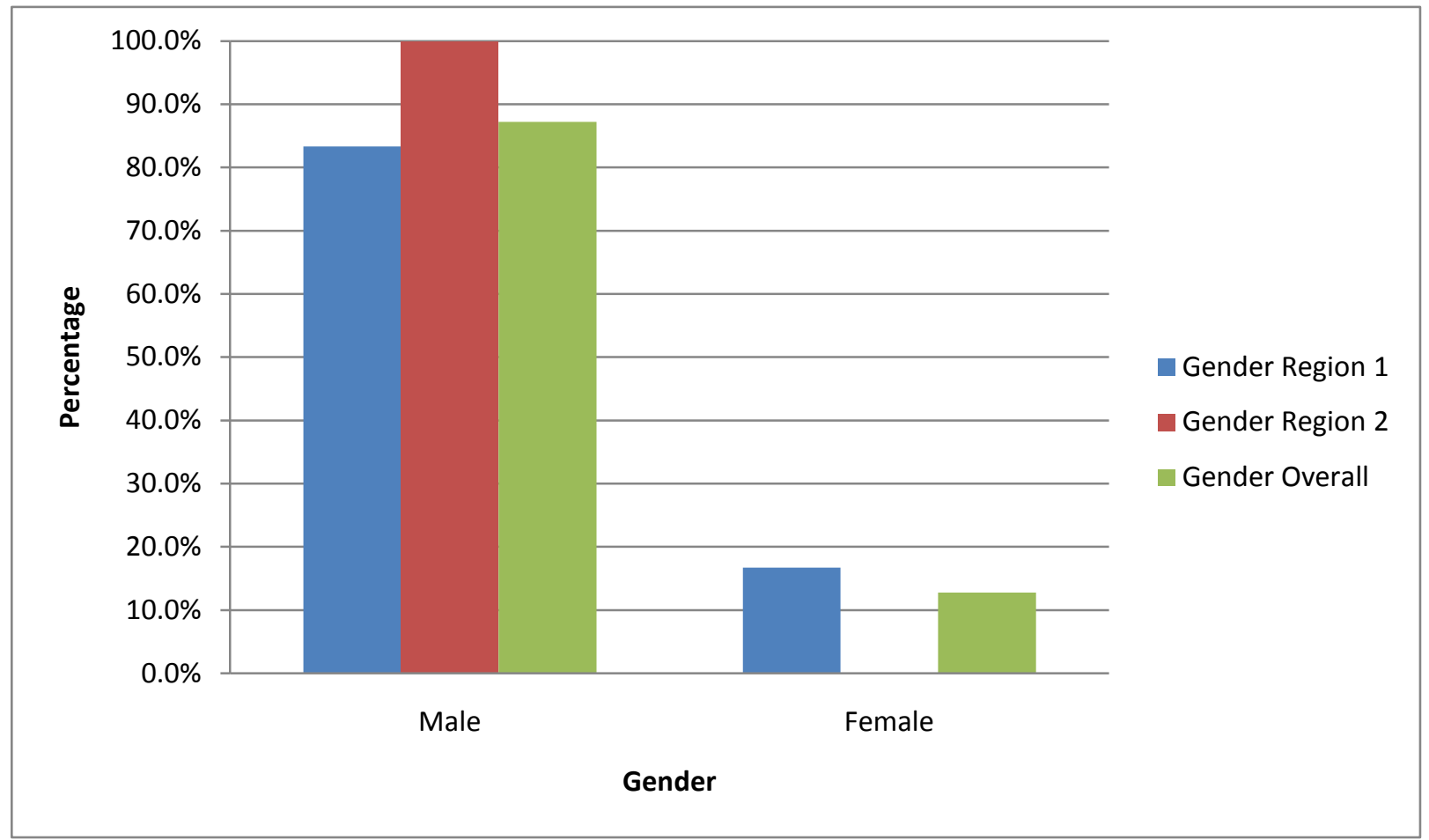

Figure 9. Distribution of farmer by gender, Andhra Pradesh and Madhya Pradesh, India, 2009.

\section{Land Ownership}

Average field size overall was 6.4 acres (Table 3). In region 1, average farm size was 4.8 acres and in region 2 the average was 11.6 acres. The difference between regions for land ownership size was not statistically significant $(\mathrm{T}$ statistic $=1.996, \mathrm{p}$ value $=0.06438)$ at the .05 level using a T-test. 
Table 3. Land ownership size, Andhra Pradesh and Madhya Pradesh, India, 2009.

\begin{tabular}{|l|c|c|c|c|c|}
\hline \multirow{2}{*}{ Region } & \multicolumn{5}{|c|}{ Acres } \\
\cline { 2 - 6 } & Mean* & Median & Min & Max & St Dev \\
\hline Region 1 & $4.8^{\mathrm{a}}$ & 2.0 & 1.0 & 55.0 & 9.1 \\
\hline Region 2 & $11.6^{\mathrm{a}}$ & 9.0 & 2.0 & 35.0 & 10.2 \\
\hline Overall & 6.4 & 3.0 & 1.0 & 55.0 & 9.7 \\
\hline
\end{tabular}

*Means within a column with same letters are not significantly different at 0.05 level using T-test.

\section{Farming Practices}

\subsection{Plantation Establishment}

All planting began in 1991 due to creation of the Andhra Pradesh Forest Produce Act, which in effect ended all arrangements between the government and ITC for supply agreements. In 2004, ITC decided to promote pulp wood plantations on farm lands after realizing that supplies from government plantations would decline in the future. This produced a large increase in the following years (Figure 10). The majority of farmers began planting in the year 2006 and after. Overall, 25.5\%, 19.1\% and $27.7 \%$ of farmers interviewed began planting in 2008, 2007 and 2006 respectively. The increases in planting in 2001, 10.6\%, was due to a breakdown in the government plantation agreement, requiring the company to source wood elsewhere, and develop private plantations. 


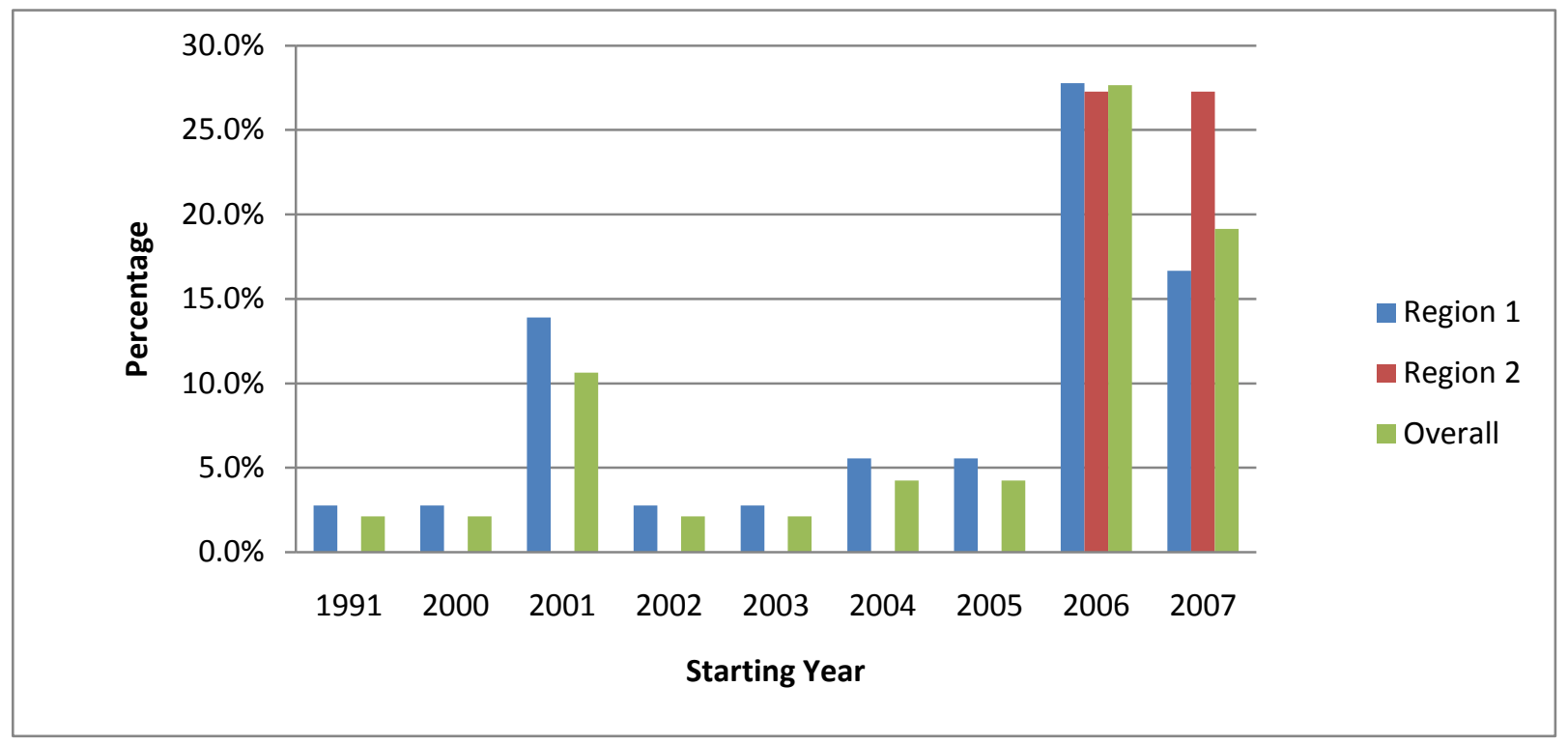

Figure 10. Distribution of starting year of planting by farmer, Andhra Pradesh and Madhya Pradesh, India, 2009. *Not statistically significant at .05 level using Chi-Square test.

In region 1, the earliest planting establishment by farmers interviewed was in 1991.

Region 1 follows the overall planting trend very closely, having the highest planting percentage in 2006 with $27.8 \%$.

Planting in region 2 started in 2006 but most (45.5\%) of the farmers interviewed did not start establishing plantation until 2008. As mentioned before, planting in this region is relatively recent due to the possibility of a new mill in the state and the competition for resources incurred by the pulp wood mill. The difference between regions for starting year was not statistically significant $\left(\mathrm{X}^{2}=6.294, \mathrm{p}\right.$ value $\left.=0.668\right)$ at the .05 level using a Chi-Square test.

\subsection{Trees Per Acre}

Overall, the average trees per acre planted by farmers were 791.9 (Table 4). In region 1, the mean trees per acre were on average 730.6 trees. In region 2 , the mean trees per acre were 
992. The difference between regions for trees per acre was statistically significant $(\mathrm{T}$ statistic $=$ 5.041, $\mathrm{p}$ value $=3.748 \mathrm{E}-5)$ at the .05 level using a T-test.

Table 4. Trees per acre planted by farmers, Andhra Pradesh and Madhya Pradesh, India, 2009.

\begin{tabular}{|c|c|c|c|c|c|}
\hline \multirow[b]{2}{*}{ Region } & \multicolumn{5}{|c|}{ TPA* } \\
\hline & Mean & Median & Min & Max & St Dev \\
\hline Region 1 & $730.6^{\mathrm{a}}$ & 600.0 & 600.0 & 1050.0 & 193.9 \\
\hline Region 2 & $992.7^{b}$ & 900.0 & 900.0 & 1200.0 & 135.1 \\
\hline Overall & 791.9 & 650.0 & 600.0 & 1200.0 & 212.5 \\
\hline
\end{tabular}

*Means with the same letter in a column are not significantly different @ 5\% level using T- test

\subsection{Rotation Age}

Overall, rotation age on average was 4.06 years (Table 5). In region 1 the mean rotation age was 4.14 years. In region 2 the mean rotation age was 3.82 years. The difference between regions for rotation age was statistically significant $(\mathrm{T}$ statistic $=2.189, \mathrm{p}$ value $=0.0406)$ at the .05 level using a T test.

Table 5. Rotation age selected by farmer, Andhra Pradesh and Madhya Pradesh, India, 2009.

\begin{tabular}{|l|c|c|c|c|c|}
\hline \multirow{2}{*}{ Region } & \multicolumn{5}{|c|}{ Number of Years } \\
\cline { 2 - 6 } & Mean & Median & Min & Max & StDev \\
\hline Region 1 & $4.14^{\mathrm{a}}$ & 4.00 & 3.00 & 5.00 & 0.49 \\
\hline Region 2 & $3.82^{\mathrm{a}}$ & 4.00 & 3.00 & 4.00 & 0.40 \\
\hline Overall & 4.06 & 4.00 & 3.00 & 5.00 & 0.48 \\
\hline
\end{tabular}

*Means with the same letter in a column are not significantly different @ 5\% level using T-test

\subsection{Plowing}

Overall, $80 \%$ of the farmers interviewed conducted plowing (Figure 11). The company recommends plowing in order to increase production from the eucalyptus by aeration of the soil and water conservation. About $75 \%$ of the farmers in region 1 plowed their plantations and about $91 \%$ of the farmers in region 2 plowed theirs. The difference between regions for plowing was not statistically significant $\left(\mathrm{X}^{2}=1.273, \mathrm{p}\right.$ value $\left.=0.259\right)$ at the .05 level using a Chi-Square test. 


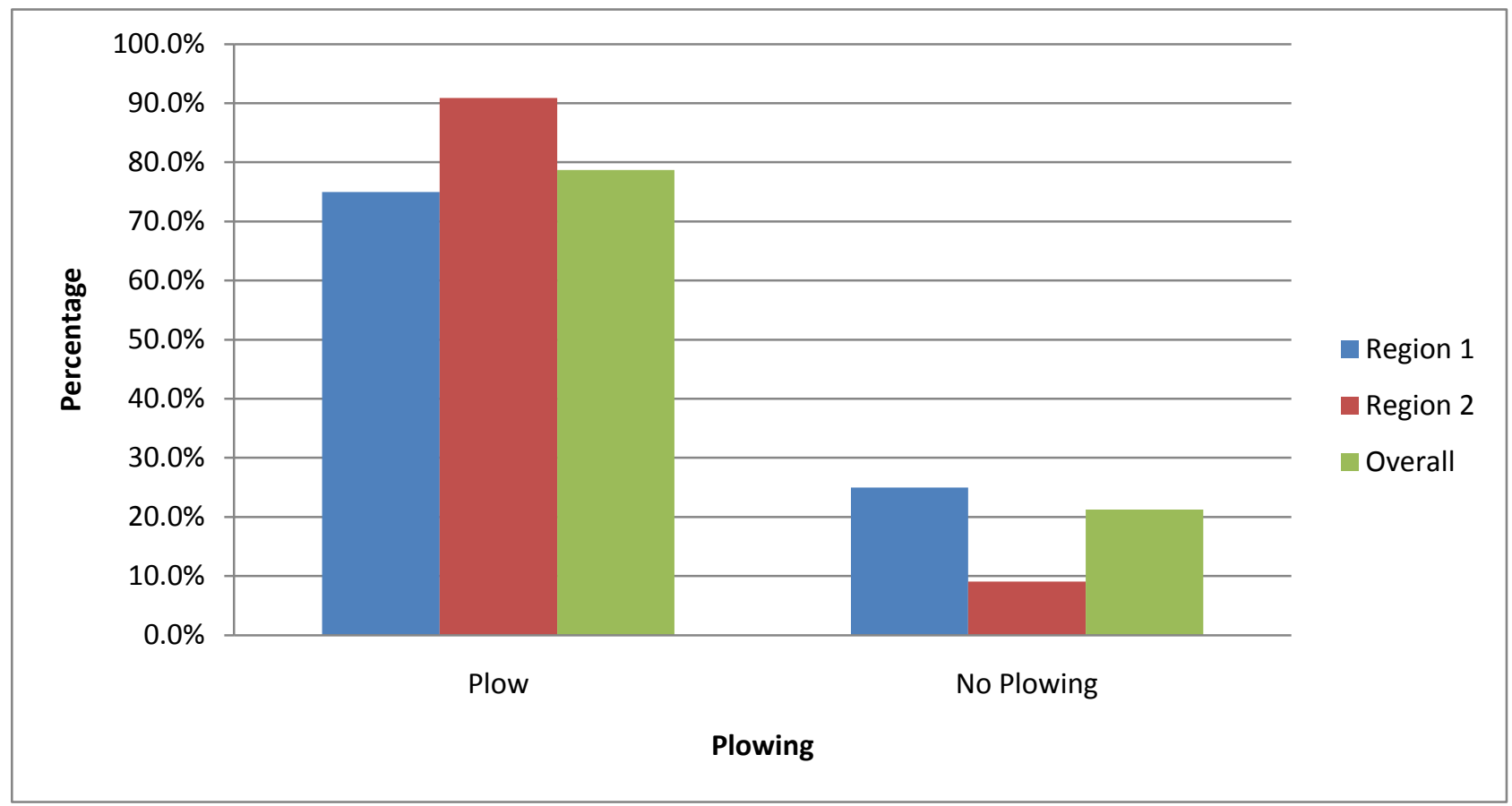

Figure 11. Distribution of farmers who conducted plowing, Andhra Pradesh and Madhya Pradesh, India, 2009. *Statistically significant at .05 level using Chi-Square test.

\subsection{Cultivation}

Overall, cultivation occurred on only $4 \%$ of the farms (Figure 12). In region 1, nearly 6\% of farmers cultivated while only $4 \%$ cultivated in region 2 . The difference between regions for cultivation was not statistically significant $\left(X^{2}=0.638, p\right.$ value $\left.=0.424\right)$ at the .05 level using a Chi-Square test. 


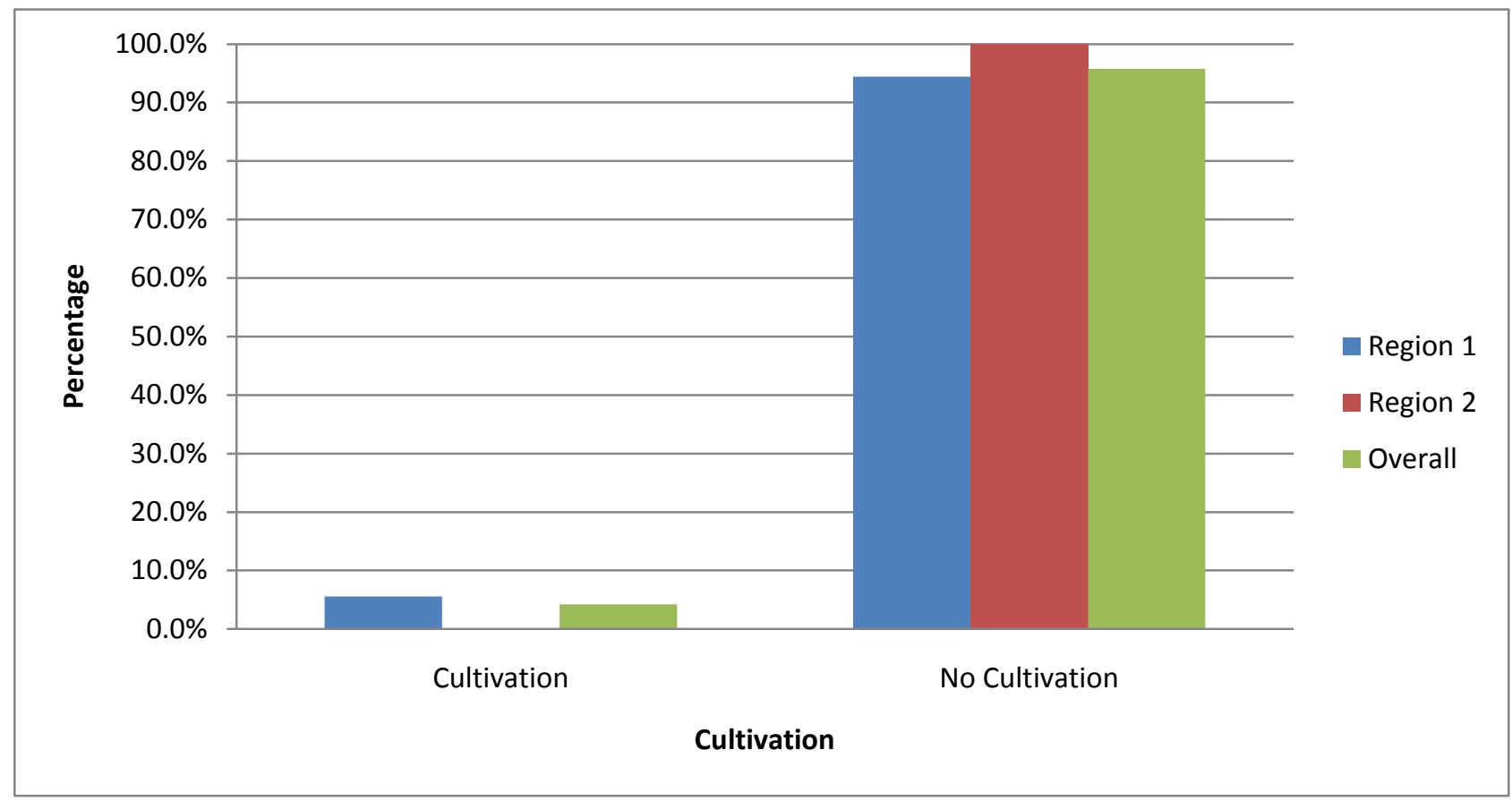

Figure 12. Distribution of farmers who conducted cultivation, Andhra Pradesh and Madhya Pradesh, India, 2009. *Not statistically significant at .05 level using Chi-Square test.

\subsection{Fertilization}

Overall, only $38 \%$ of the farmers applied fertilization while the majority did not fertilize (Figure 13). However, looking only at region 1, 50\% of the farmers fertilized and $50 \%$ did not fertilize. In region 2, no farmers fertilized. The farmers are advised to fertilize in the form of NPK twice every year. The occurrence of fertilization by farmers between the two regions was statistically significant $\left(\mathrm{X}^{2}=8.914, \mathrm{p}\right.$ value $\left.=0.003\right)$ at the .05 level using a Chi-Square test. 


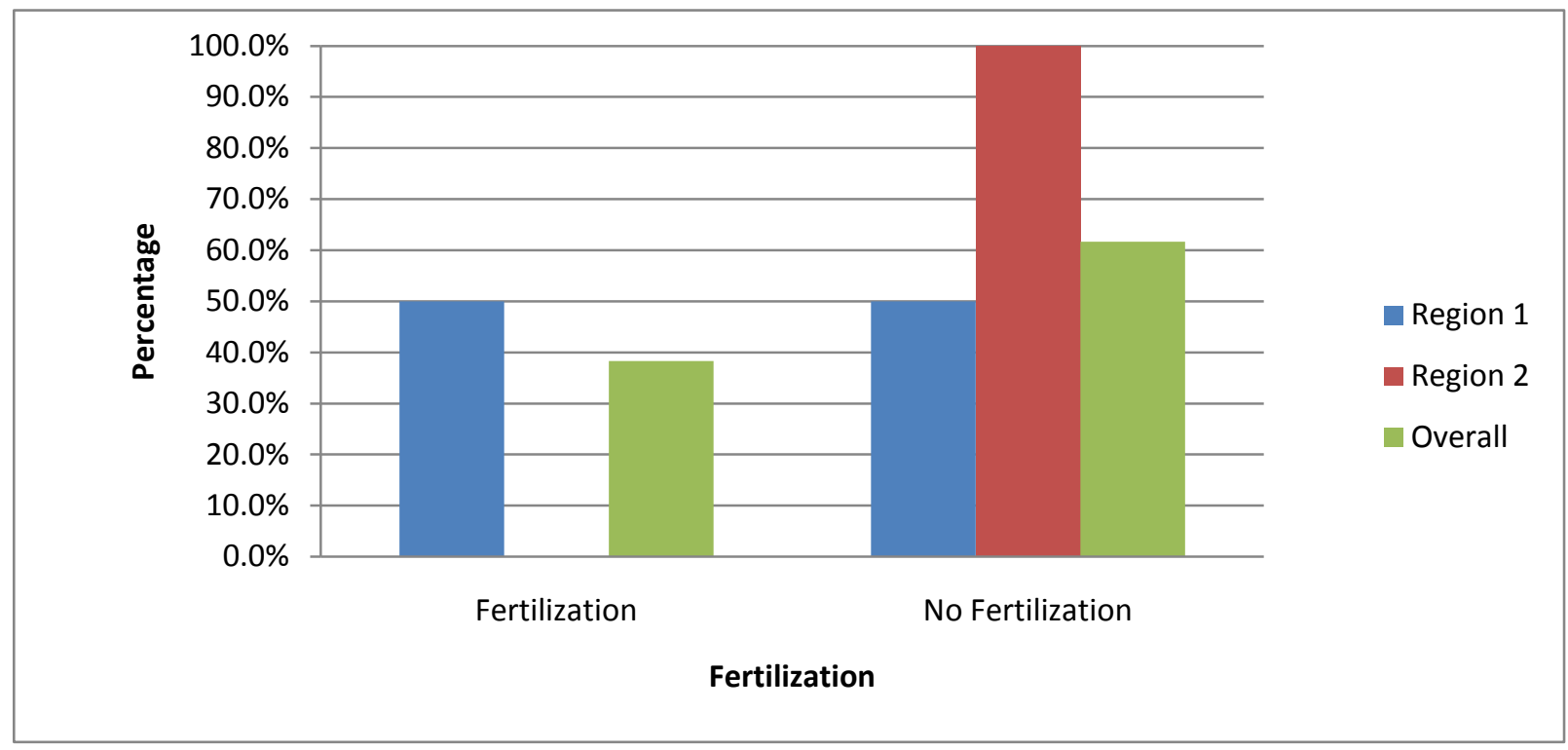

Figure 13. Distribution of farmers who applied fertilizer, Andhra Pradesh and Madhya Pradesh, India, 2009. *Statistically significant at .05 level using Chi-Square test.

\subsection{Irrigation}

Overall, $8.5 \%$ of the farmers irrigated their farms (Figure 14). In fact, only farmers from region 1 applied irrigation (11\%) while none of the farmers in region 2 irrigated. The difference between regions for irrigation was not statistically significant $\left(X^{2}=1.336, p\right.$ value $\left.=0.248\right)$ at the .05 level using a Chi-Square test. 


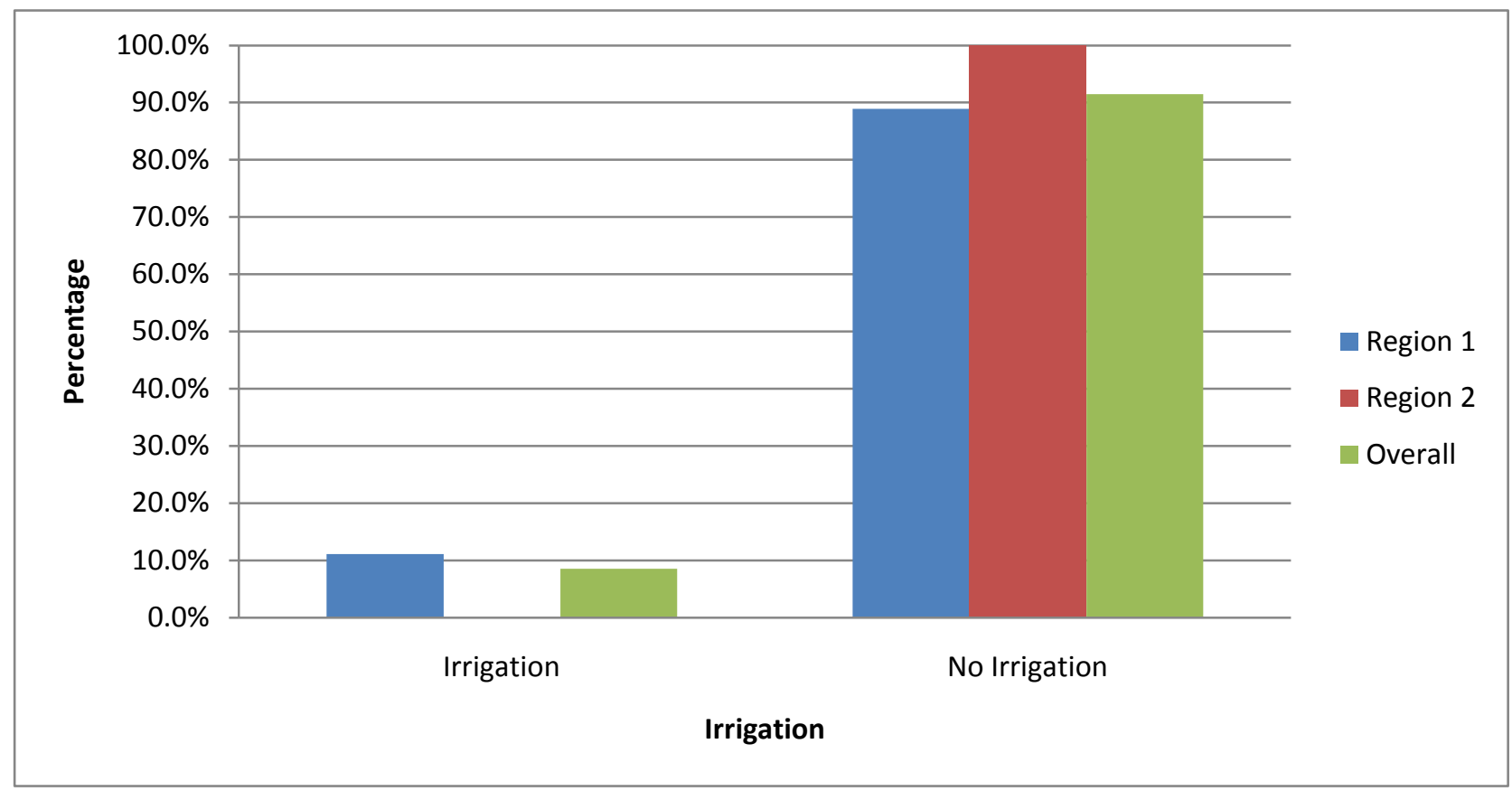

Figure 14. Distribution of farmers who conducted irrigation, Andhra Pradesh and Madhya Pradesh, India, 2009. *Not statistically significant at .05 level using Chi-Square test.

\subsection{Farm Yard Manure Application}

The application of farm yard manure occurred on only $2 \%$ of the overall farms (Figure 15). In region 1, 3\% of farmers applied farm yard manure while no farmers in region 2 applied farm yard manure. The difference between regions for application of farm yard manure was not statistically significant $\left(\mathrm{X}^{2}=0.312, \mathrm{p}\right.$ value $\left.=0.576\right)$ at the .05 level using a Chi-Square test. 


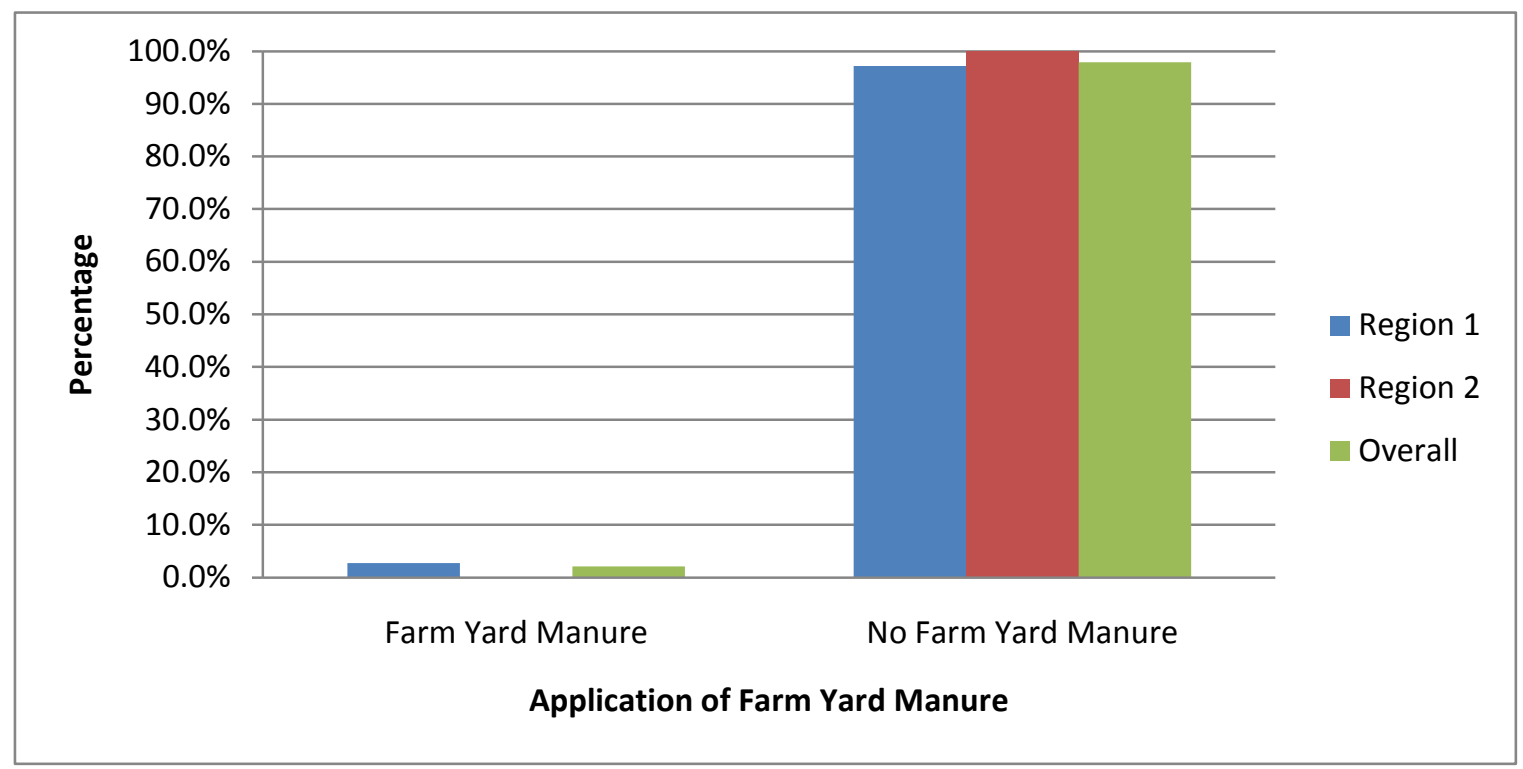

Figure 15. Distribution of farmers who applied farm yard manure, Andhra Pradesh and Madhya Pradesh, India, 2009. *Not statistically significant at .05 level using Chi-Square test.

\subsection{Insecticide}

The application of insecticide occurred on only $2 \%$ of the overall farms (Figure 16). The application of Phorate is recommended at the time of planting to protect saplings against root grub. In region 1, 3\% of farmers applied insecticide. In region 2, no farmers applied insecticide. The difference between regions for application of insecticide was not statistically significant $\left(\mathrm{X}^{2}\right.$ $=0.312, \mathrm{p}$ value 0.576$)$ at the .05 level using a Chi-Square test. 


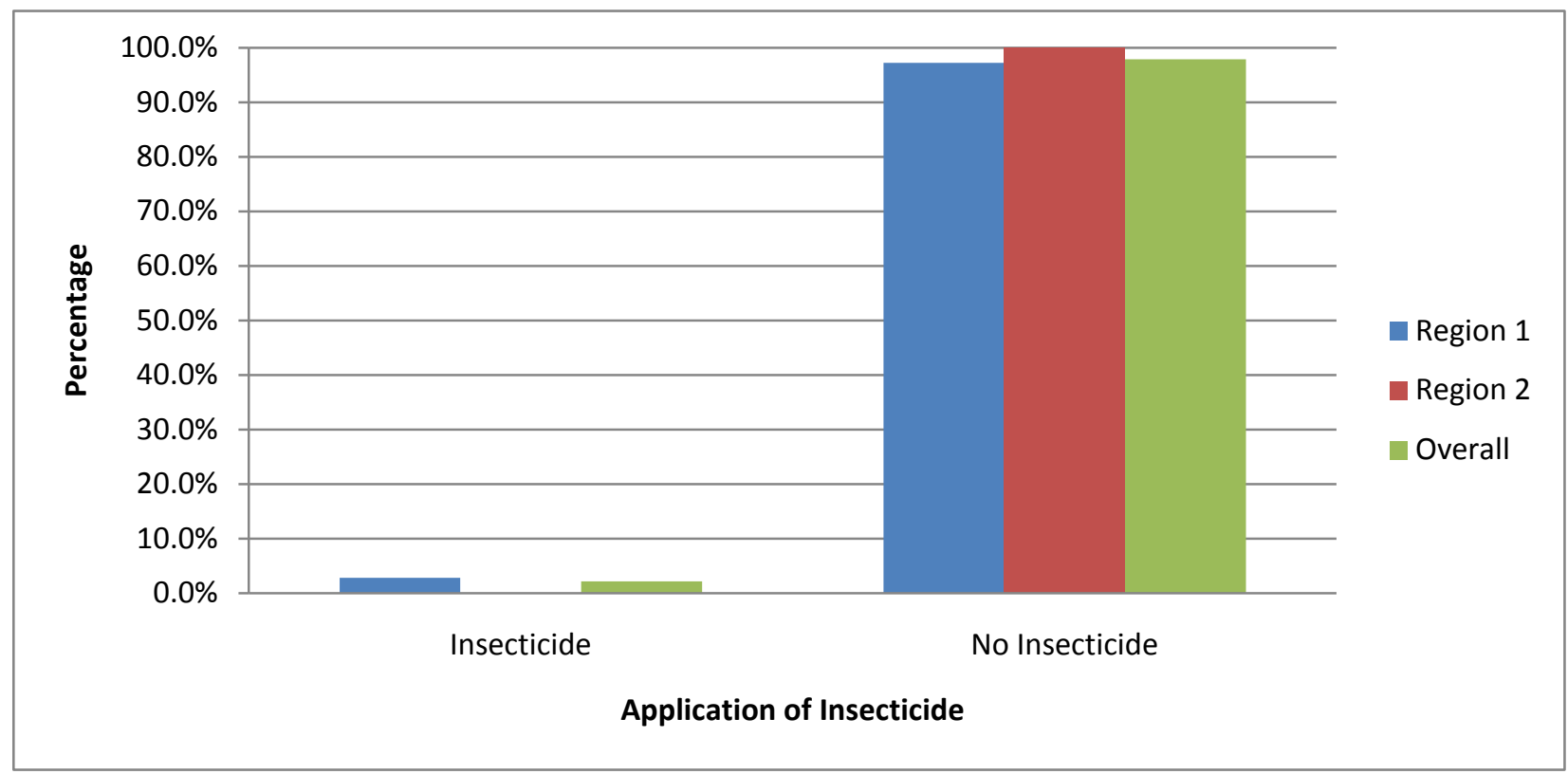

Figure 16. Distribution of farmers who applied insecticide, Andhra Pradesh and Madhya Pradesh, India, 2009. *Not statistically significant at .05 level using Chi-Square test.

\subsection{Spacing}

Determining which spacing option to use for growing eucalyptus can greatly affect the intercrop that has been chosen to grow beneath it. The research shows five variations on spacing techniques used in the study area. These spacing options are $3 \mathrm{~m} \times 2 \mathrm{~m}, 2.74 \times 1.37 \mathrm{~m}, 3 \mathrm{~m} \times 1.5 \mathrm{~m}$, $8 \mathrm{~m} \times 1 \mathrm{~m} \times 1 \mathrm{~m}$ and $3 \mathrm{~m} \times 1 \mathrm{~m} \times 1 \mathrm{~m}$. The $8 \times 1 \times 1$ and $3 \times 1 \times 1$ spacing patterns are in a paired row format, meaning that there is $8 \mathrm{~m}$ or $3 \mathrm{~m}$ respectively between two rows and $1 \mathrm{~m}$ between each row and tree in that row. The $3 \times 2$ and $2.74 \times 1.37 \mathrm{~m}$ were only used in region $1,3 \times 1.5$ was used in both regions and the two paired rows $8 \times 1 \times 1$ and $3 \times 1 \times 1$ were only used in region 2 (Figure 17). 


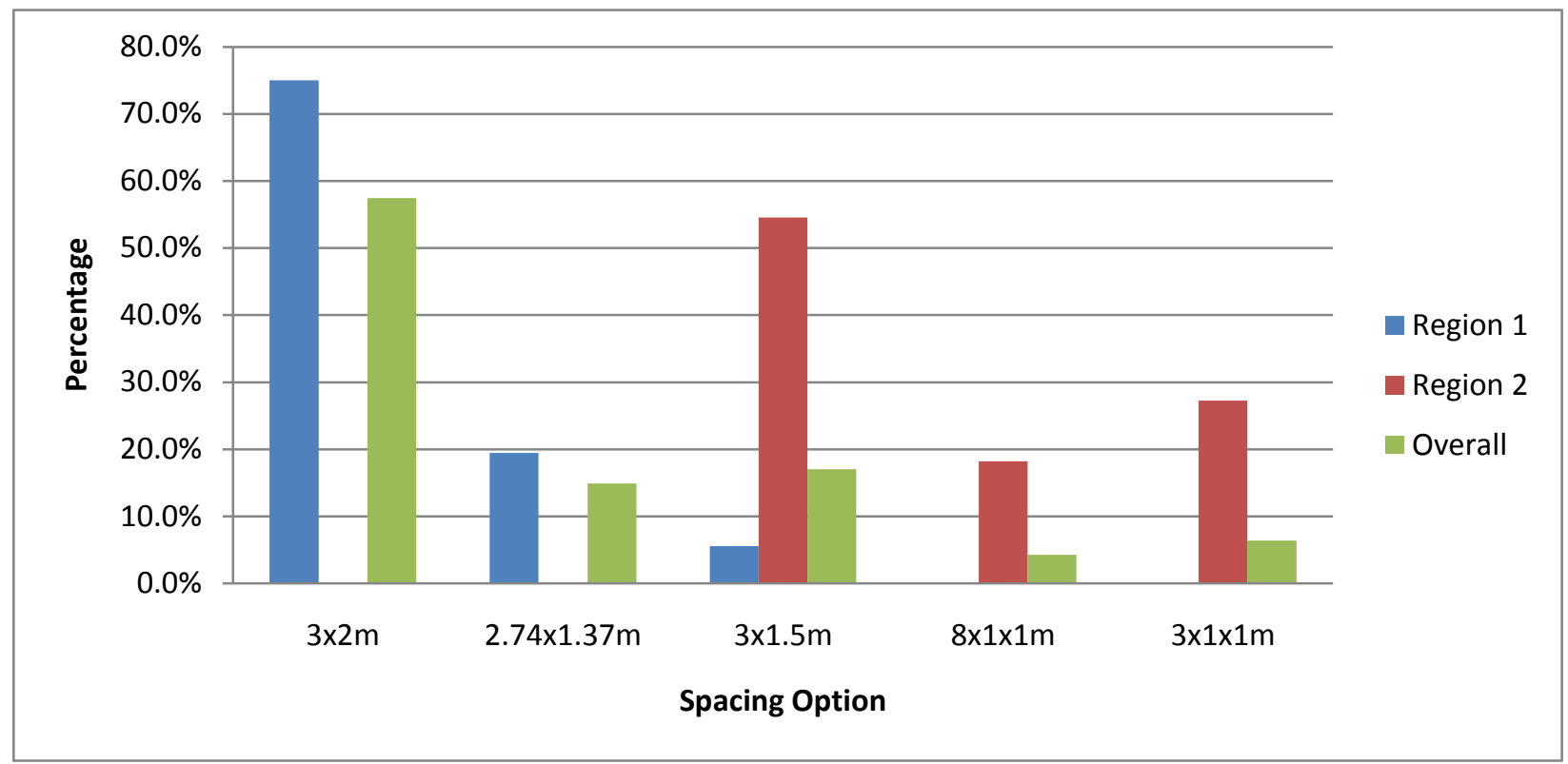

Figure 17. Distribution of farmers by spacing option used, Andhra Pradesh and Madhya Pradesh, India, 2009. *Statistically significant at .05 level using Chi-Square test.

The $3 \mathrm{mx} 2 \mathrm{~m}$ spacing allows for 600 trees per acre and was the overall most used option, being used $57 \%$ of the time, and also by all of the female participants interviewed. The $2.74 \times 1.37 \mathrm{~m}$ spacing allows for 1050 trees per acre and was used only $15 \%$ of the time by the farmers studied. Both of these spacing options were only used with an intercrop for the first year, since farmers found it to shade out any possible intercrop after the first growing season. The $3 \mathrm{mx} 2 \mathrm{~m}$ was the overall most popular spacing used, and in region 1 was by far the most popular at $75 \%$ of the time used. This spacing option allowed farmers to grow an intercrop in the first year only. The $2.74 \times 1.37 \mathrm{~m}$ spacing was used $19 \%$ of the time in region 1 . With the lower number of trees, this spacing scheme was favorable to farmers because it requires a lower upfront cost. The $3 \mathrm{mx} 1.5 \mathrm{~m}$ spacing allows for 900 trees per acre and was used $17 \%$ of the time. This spacing was used in both regions. In region 1 it was only used $6 \%$ of the time and in region 2 it was the most popular spacing and was used $55 \%$ of the time. The two paired row systems were only used in region 2 . The $8 \mathrm{mx} 1 \mathrm{mx} 1 \mathrm{~m}$ spacing allows 960 trees per acre and was used $4 \%$ 
of the time overall and $18 \%$ in region 2 . The $3 \mathrm{mx} 1 \mathrm{mx} 1 \mathrm{~m}$ allows 1200 trees per acre and was used $6 \%$ of the time overall and $27 \%$ of the time in region 2.

\subsection{Intercrop}

Overall, intercrops were used $83 \%$ of the time (Figure 18). Seventeen percent of the farmers interviewed did not plant an intercrop along with their eucalyptus plantations. In region 1 , nearly $78 \%$ of the farmers planted an intercrop compared to $22 \%$ that did not. In region 2 , all farmers planted an intercrop. The difference between regions for growing an intercrop was not statistically significant $\left(\mathrm{X}^{2}=2.946, \mathrm{p}\right.$ value $\left.=0.086\right)$ at the .05 level using a Chi-Square test.

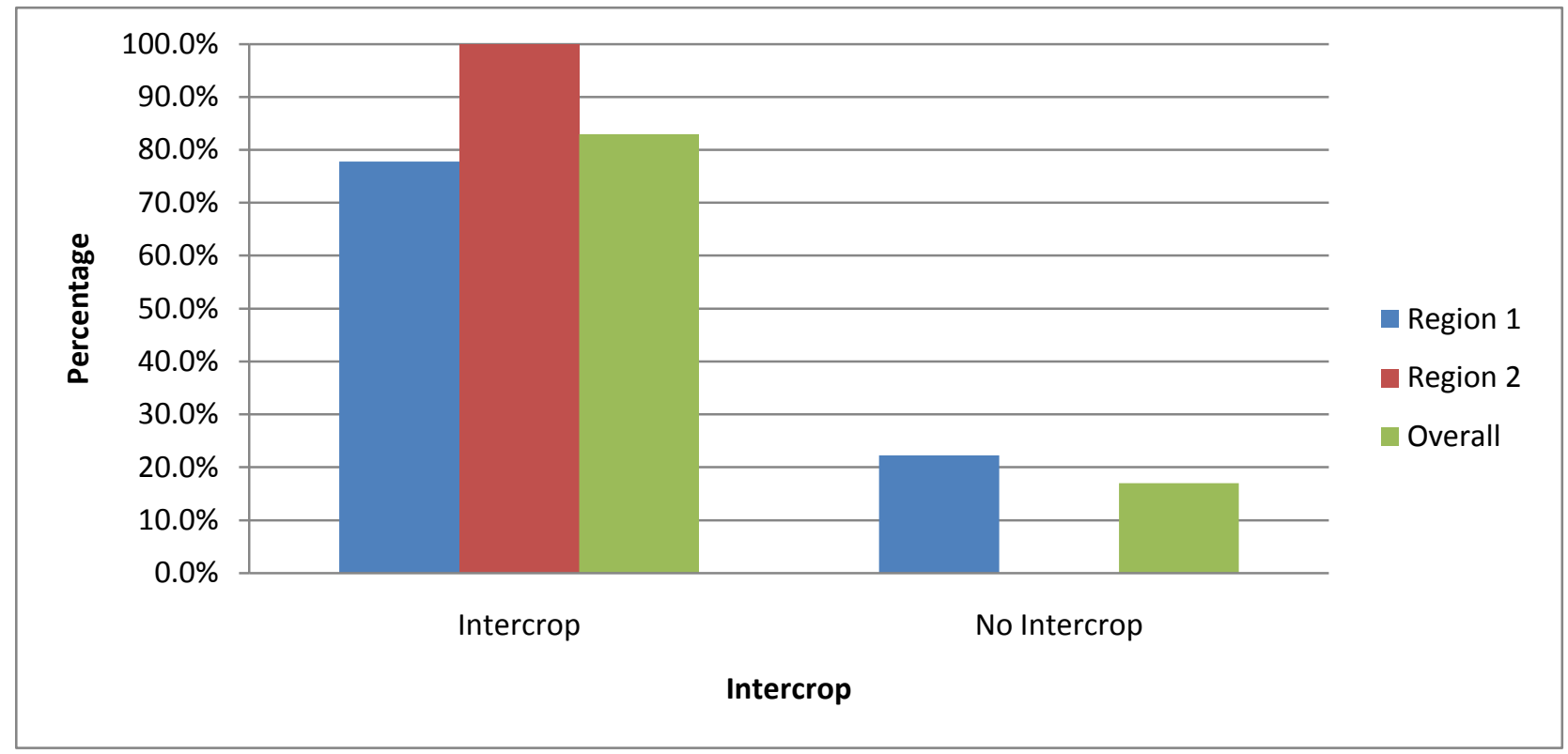

Figure 18. Distribution of farmers who conducted intercropping, Andhra Pradesh and Madhya Pradesh, India, 2009. *Not statistically significant at .05 level using Chi-Square test.

Overall, most of the farmers (62\%) only applied one intercrop (Figure 19). In region 1, $72 \%$ applied one intercrop while in region 2, majority (55\%) had two years of intercrops. The number of intercrops grown by farmers between the two regions was statistically significant $\left(\mathrm{X}^{2}\right.$ $=27.215, \mathrm{p}$ value $=1.40364 \mathrm{E}-05)$ at the .05 level using a Chi-Square test. 


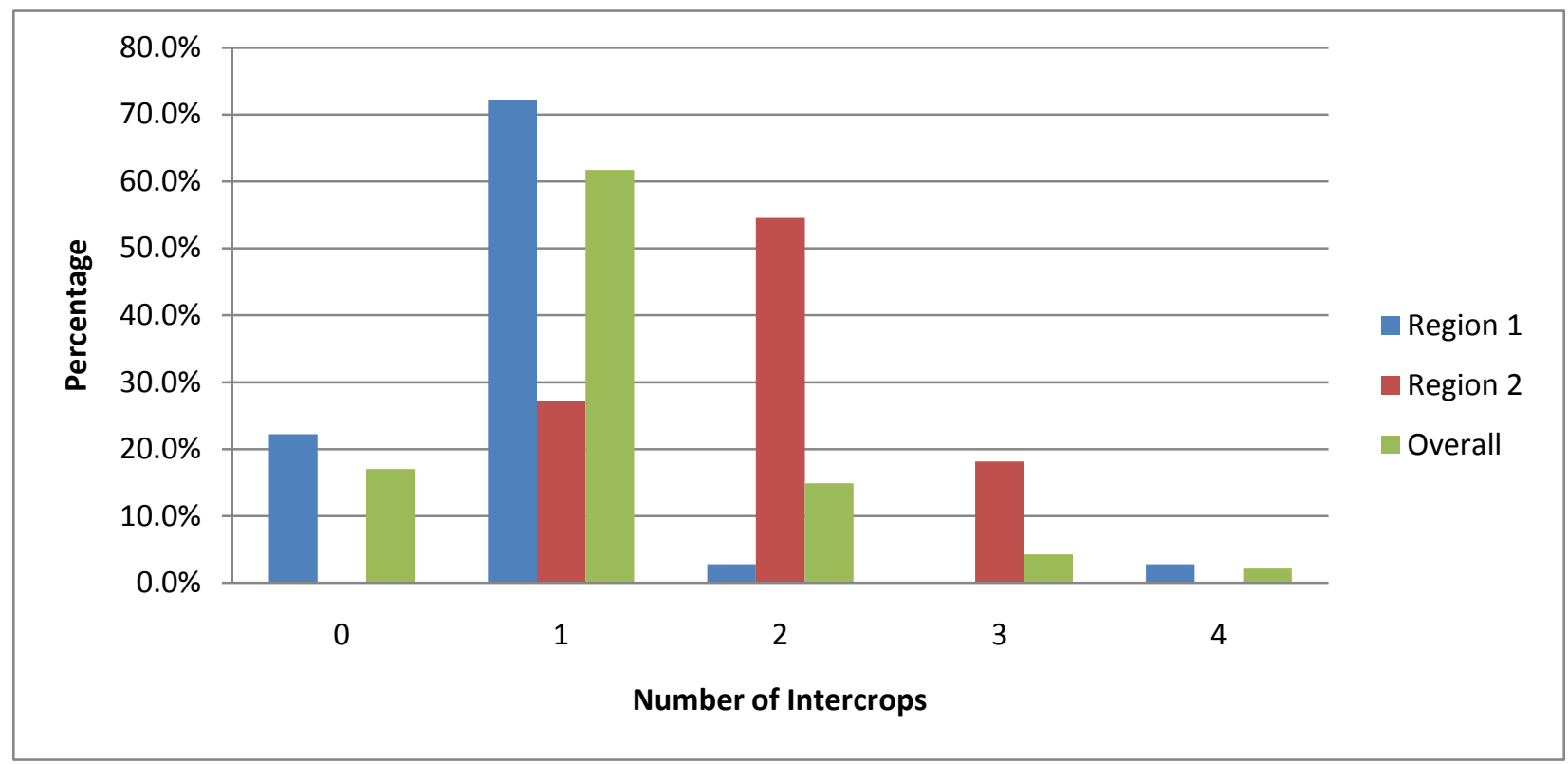

Figure 19. Distribution of farmers by number of intercrops applied, Andhra Pradesh and Madhya Pradesh, India, 2009. *Statistically significant at .05 level using Chi-Square test.

The most common intercrop was cotton, planted by 17 farmers (Table 6). Other common intercrops were Chili, Black gram, tobacco, and multiple combinations of crops.

Table 6. Species used in intercropping by farmers in Andhra Pradesh and Madhya Pradesh, India, 2009.

\begin{tabular}{|c|c|}
\hline Intercrop Species & Number of Farmers \\
\hline Cotton & 17 \\
\hline Chili & 5 \\
\hline Black Gram & 2 \\
\hline Tobacco & 2 \\
\hline Green Pea/Lemon Grass & 2 \\
\hline Soya/Bengal Gram/Wheat & 1 each \\
Green Gram/Paddy, Bottle Gourd/Tomato, \\
Bottle Gourd/Flower, Bengal Gram, Green \\
Pea, Wheat
\end{tabular}




\section{Cost of Farming Practices}

Plowing cost overall between regions on average was $\$ 30.70 /$ acre, (Table 7) and was statistically significant $(\mathrm{T}$ statistic $=5.417, \mathrm{p}$ value $=5.89 \mathrm{E}-6)$ at the .05 level using a $\mathrm{T}$-test. Cultivation, fertilization, irrigation farm yard manure application and insecticide did not occur in region 2. Average cultivation cost for region 1 was $\$ 12.50$, fertilizer cost was $\$ 20.70$, with a median of $\$ 19.80$; irrigation cost was $\$ 32.80$ farm yard manure was $\$ 12.50$ and insecticide cost was $\$ 16.70$.

Intercrop planting cost for year 1 overall on average was $\$ 185.90$, region 1 was $\$ 219.80$ and region 2 was $\$ 99.40$ (Table 7). The difference between regions for intercrop planting in year 1 was not statistically significant $(\mathrm{T}$ statistic $=1.779, \mathrm{p}$ value $=0.0837)$ at the .05 level using a $\mathrm{T}$ test.

Intercrop planting cost for year 2 overall on average was $\$ 198.60$, region 1 was $\$ 522.90$ and region 2 was $\$ 106$ (Table 7). The difference between regions for year 2 cost was not statistically significant $(\mathrm{T}$ statistic $=0.803, \mathrm{p}$ value $=0.569)$ at the .05 level using a T-test. Intercrop planting cost for year 3 overall on average was $\$ 59.90$, region 1 was $\$ 4.20$ and region 2 the mean $\$ 78.50$. Intercrop planting cost for year 3 overall and for region 1 were the same at $\$ 4.20$. 
Table 7.Cost of farming practices (\$/acre), Andhra Pradesh and Madhya Pradesh, India, 2009.

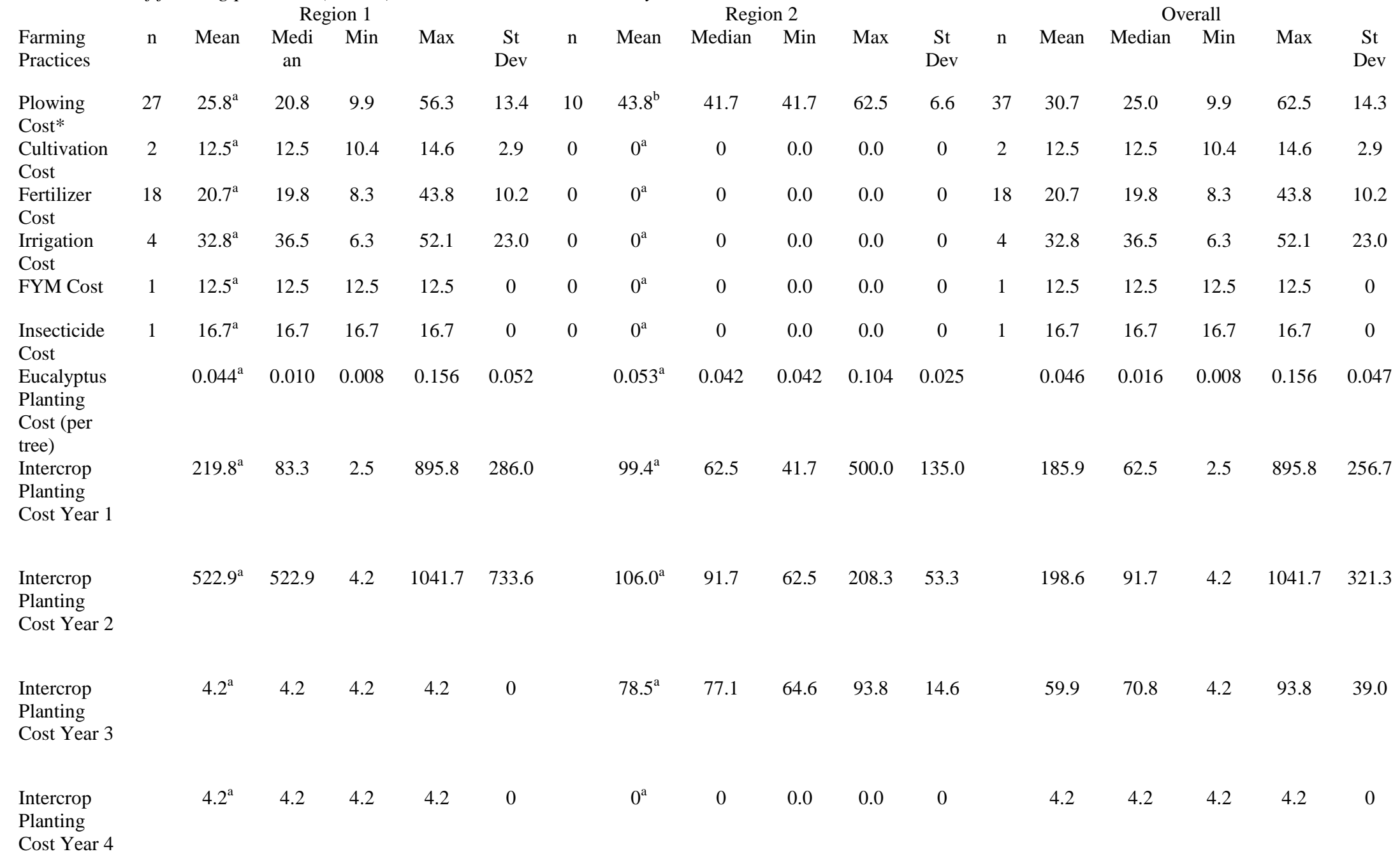

*Means with same letters in a row are not significantly different at .05 level using Ttest Values are in Dollars, 1USD=48INR July 2009 


\section{Revenues from Farming Practices}

Intercrop revenue for year 1 overall on average was $\$ 308.30$, region 1 was $\$ 367.10$ and region 2 was $\$ 158.90$ (Table 8). The difference between regions for year 1 intercrop revenue was statistically significant $(\mathrm{T}$ statistic $=2.227, \mathrm{p}$ value $=0.0324)$ at the .05 level using a T-test.

Intercrop revenue for year 2 overall on average was $\$ 381.00$, region 1 was $\$ 385.40$ and region 2 was $\$ 379.80$ (Table 8). The difference between regions for year 2 intercrop revenue was not statistically significant $(\mathrm{T}$ statistic $=0.0172, \mathrm{p}$ value $=0.989)$ at the .05 level using a T-test.

Intercrop revenue for year 3 overall on average was $\$ 302.10$, for region 1 was $\$ 83.30$ and region 2 was $\$ 356.80$. Intercrop revenue for year 4 overall on average was $\$ 201.40$, for region 1 was $\$ 83.30$ and for region 2 was $\$ 260.40$.

Eucalyptus total revenue overall on average was $\$ 1535.10$, region 1 was $\$ 977.00$ and region 2 the mean revenue was $\$ 3361.70$. The difference between regions for eucalyptus total revenue was statistically significant $(\mathrm{T}$ statistic $=19.272, \mathrm{p}$ value $=1.558 \mathrm{E}-21)$ at the .05 level using a T-test.

\section{Eucalyptus Yield and Price}

Overall, the average eucalyptus yield was 28.2 tons per acre (Table 9). In region 1, the mean yield was on average 24.3 tons/ac while in region 2 , the mean yield was 40.9 tons/ac. The difference between regions for eucalyptus yield was statistically significant $(\mathrm{T}$ statistic $=7.080, \mathrm{p}$ value $=8.712 \mathrm{E}-9)$ at the .05 level using a T-test. 
Table 8. Revenue values for farming practices (\$/acre), Andhra Pradesh and Madhya Pradesh, India, 2009.

\begin{tabular}{|c|c|c|c|c|c|c|c|c|c|c|c|c|c|c|c|}
\hline \multirow[b]{2}{*}{$\begin{array}{l}\text { Revenue } \\
\text { Categories }\end{array}$} & \multicolumn{5}{|c|}{ Region 1} & \multicolumn{5}{|c|}{ Region 2} & \multicolumn{5}{|c|}{ Overall } \\
\hline & Mean & Median & Min & Max & $\begin{array}{c}\text { St } \\
\text { Dev }\end{array}$ & Mean & Median & Min & $\operatorname{Max}$ & $\begin{array}{c}\text { St } \\
\text { Dev }\end{array}$ & Mean & Median & Min & Max & St Dev \\
\hline Intercrop & & & & & & & & & & & & & & & \\
\hline $\begin{array}{l}\text { Revenue Year } 1 * \\
\text { Intercrop }\end{array}$ & $367.1^{\mathrm{a}}$ & 197.9 & 27.3 & 1666.7 & 448.9 & $158.9^{\mathrm{b}}$ & 125.0 & 41.7 & 508.3 & 130.0 & 308.3 & 177.1 & 27.3 & 1666.7 & 395.8 \\
\hline $\begin{array}{l}\text { Revenue Year } 2 \\
\text { Intercrop }\end{array}$ & $385.4^{\mathrm{a}}$ & 385.4 & 83.3 & 687.5 & 427.2 & $379.8^{\mathrm{a}}$ & 262.5 & 125.0 & 1041.7 & 334.6 & 381.0 & 262.5 & 83.3 & 1041.7 & 326.8 \\
\hline $\begin{array}{l}\text { Revenue Year } 3 \\
\text { Intercrop }\end{array}$ & $83.3^{\mathrm{a}}$ & 83.3 & 83.3 & 83.3 & 0 & $356.8^{\mathrm{a}}$ & 349.0 & 125.0 & 604.2 & 208.7 & 302.1 & 260.4 & 83.3 & 604.2 & 218.3 \\
\hline $\begin{array}{l}\text { Revenue Year } 4 \\
\text { Euca Total }\end{array}$ & $83.3^{\mathrm{a}}$ & 83.3 & 83.3 & 83.3 & 0 & $260.4^{\mathrm{a}}$ & 260.4 & 260.4 & 260.4 & 0.0 & 201.4 & 260.4 & 83.3 & 260.4 & 102.2 \\
\hline Revenue* & $977.0^{\mathrm{a}}$ & 810.4 & 225.0 & 4375.0 & 722.6 & $3361.7^{b}$ & 3333.3 & 3333.3 & 3645.8 & 94.2 & 1535.1 & 937.5 & 225.0 & 4375.0 & 1200.4 \\
\hline
\end{tabular}

Table 9.Eucalyptus yield and price values, Andhra Pradesh and Madhya Pradesh, India, 2009.

$$
\text { Region } 1 \quad \text { Region } 2
$$

Mean Median Min Max St Dev Mean Median Min Max St Dev Mean Median Min Max St Dev

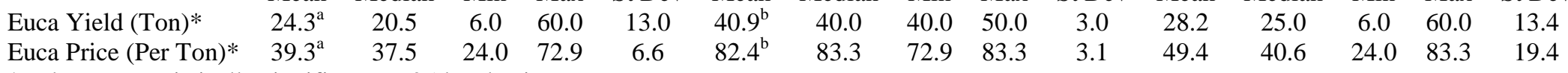

*Values are statistically significant at .05 level using Ttest

Values are in Dollars, 1USD=48INR July 2009 
The overall average eucalyptus price per ton was $\$ 49.40$. In region 1 , the mean price was $\$ 39.30$. In region 2 , the mean price was higher with farmers receiving $\$ 82.40$ per ton. The difference between regions for eucalyptus price per ton was statistically significant $(\mathrm{T}$ statistic $=$ 29.690, p value 6.538E-27) at the .05 level using a T-test.

\section{Financial Analysis}

Based on the positive values of NPV, BCR, EIA, and LEV, converting traditional croplands to agroforestry are financially feasible using $12 \%$ discount rate (Table 10). In addition, IRR in both regions are greater that the discount rate used in the study, indicating the feasibility of the system.

Table 10. Summary of the results of financial analysis for converting traditional agricultural croplands into agroforestry in Andhra Pradesh and Madhya Pradesh, India, 2009.

\begin{tabular}{|c|c|c|c|c|c|c|c|c|}
\hline & \multicolumn{3}{|c|}{ Andhra Pradesh } & \multicolumn{5}{c|}{ Madhya Pradesh } \\
\hline $\begin{array}{c}\text { Discount } \\
\text { Rate }\end{array}$ & NPV & $\begin{array}{c}\text { B/C } \\
\text { Ratio }\end{array}$ & EAI & LEV & NPV & $\begin{array}{c}\text { B/C } \\
\text { Ratio }\end{array}$ & EAI & LEV \\
\hline 6 & $\$ 711.18$ & 2.09 & $\$ 16.62$ & $\$ 7266.41$ & $\$ 3394.09$ & 8.04 & $\$ 79.35$ & $\$ 15556.66$ \\
\hline 12 & $\$ 587.88$ & 1.94 & $\$ 31.89$ & $\$ 1366.75$ & $\$ 2903.26$ & 7.35 & $\$ 157.53$ & $\$ 7262.07$ \\
\hline 16 & $\$ 519.81$ & 1.86 & $\$ 41.37$ & $\$ 2524.33$ & $\$ 2629.01$ & 6.93 & $\$ 209.24$ & $\$ 5208.63$ \\
\hline IRR & \multicolumn{3}{|c|}{$28 \%$} & \multicolumn{5}{|c|}{$74 \%$} \\
\hline
\end{tabular}

Sensitivity analysis using different discount rates was conducted to examine how changes in discount rate would affect the financial feasibility of the agroforestry system. Even with the changes in discount rate, the agroforestry system in both regions are still financially feasible. Even with the incorporation of land value in the analysis (i.e., opportunity cost of the land, in this case LEV), the agroforestry schemes are still financially viable in both Andhra Pradesh and Madhya Pradesh at all discount rates used (Table 11). However, as expected, there is a significant reduction in the magnitude of the different financial criteria, particularly the IRR. IRR 
with LEV included at 12\%, is 17\% for Andhra Pradesh and 16\% for Madhya Pradesh. NPV at 12\% is 194.66 for Andhra Pradesh and 810.19 for Madhya Pradesh.

Table 11. Summary of the results of financial analysis for converting traditional agricultural croplands into agroforestry including land estimation value in Andhra Pradesh and Madhya Pradesh, India, 2009.

\begin{tabular}{|c|c|c|c|c|c|c|c|c|}
\hline & \multicolumn{4}{|c|}{ Andhra Pradesh } & \multicolumn{4}{c|}{ Madhya Pradesh } \\
\hline $\begin{array}{c}\text { Discount } \\
\text { Rate }\end{array}$ & NPV & $\begin{array}{c}\text { B/C } \\
\text { Ratio }\end{array}$ & EAI & IRR & NPV & $\begin{array}{c}\text { B/C } \\
\text { Ratio }\end{array}$ & EAI & IRR \\
\hline 6 & $\$ 492.68$ & 1.24 & $\$ 11.52$ & $4 \%$ & $\$ 2229.40$ & 1.29 & $\$ 52.12$ & $8 \%$ \\
\hline 12 & $\$ 194.66$ & 1.10 & $\$ 10.56$ & $17 \%$ & $\$ 810.19$ & 1.10 & $\$ 43.96$ & $16 \%$ \\
\hline 16 & $\$ 29.38$ & 1.01 & $\$ 2.34$ & $10 \%$ & $\$ 19.44$ & 1.00 & $\$ 1.55$ & $22 \%$ \\
\hline
\end{tabular}

\section{Factors Affecting Financial Feasibility of Agroforestry}

Factors that significantly influence the feasibility of converting traditional croplands into agroforestry system include region, the starting year of agroforesty establishment, plowing cost, irrigation cost, spacing, trees per acre, number of intercrops used, type of intercrops used, intercrop cost, intercrop revenues, and eucalyptus plantation revenues (Table 12). Farmers who converted to agroforestry plantation recently tended to have higher NPV as shown by the negative sign of START variable. NPV is positively influenced by both the intercrop and eucalyptus plantation revenues, as expected. Spacing and trees per acre also positively influenced NPV. The larger the spacing, the higher the NPV, all other factors constant. The more trees per acre planted, the higher the NPV. The results of the model also indicate that farmers in Madhya Pradesh have higher NPVs. The number of intercrops used also positively influenced NPV. The more intercrops planted by the farmers, the higher the NPV. In terms of the type intercrops used, farmers using cotton as an intercrop tended to have lower NPV compared to farmers using other agricultural crops (e.g., chili, tomato, gram). Most of the variables representing costs of farm practices (IRRIGATE and INTERCOST), as expected, have a negative influence on NPV. However, plowing cost had a positive influence on NPV, contrary to expectation. Farmer characteristics such as education and gender are not significant factors as well as other cost 
variables like fertilization, irrigation and planting costs. Size of the farm is also not a significant determinant of the feasibility of agroforestry.

Table 12. Results of regression analysis for the model that examines the factors affecting financial feasibility of converting traditional farms into agroforestry plantation in Andhra Pradesh and Madhya Pradesh, India, 2009.

\begin{tabular}{|c|c|c|}
\hline Variables & Parameter Estimates & Standard Error \\
\hline Constant & $-153121.37 * * *$ & 27938.44 \\
\hline REGION & $59489.47 * * *$ & 18053.61 \\
\hline EDUC & -3688.81 & 2521.39 \\
\hline GENDER & 9674.81 & 6149.86 \\
\hline ACRES & -187.59 & 311.21 \\
\hline START & $-3164.69 * *$ & 1268.41 \\
\hline PLOW & $8.68^{* *}$ & 3.51 \\
\hline CULTIVATE & -14.82 & 17.36 \\
\hline FERTILIZE & -5.04 & 5.84 \\
\hline IRRIGATE & $-15.60 * * *$ & 4.55 \\
\hline SPACE & $14937.58 * * *$ & 3761.87 \\
\hline TPA & $102.06 * * *$ & 32.59 \\
\hline INTERCROP & $12991.92 * * *$ & 3011.13 \\
\hline INTERCOST & $-26058.84 * * *$ & 8530.30 \\
\hline INTEREV & $3011.10 * * *$ & 2481.84 \\
\hline COTTON & $-1.39 * * *$ & 0.30 \\
\hline PLANTCOST & 0.94 & 0.19 \\
\hline PLANTREV & $0.19 * * *$ & 0.07 \\
\hline \multicolumn{3}{|l|}{$\begin{array}{l}\text { F-Statistic }=96.00 \\
P-\text { value }=0.000 \\
R^{2}=0.98 \\
N=47\end{array}$} \\
\hline
\end{tabular}

*Significant at $1 \%$ level, **Significant at $5 \%$ level, ***Significant at $10 \%$ level 


\section{Discussion}

This study investigated commercially promoted agroforestry schemes in two states in India. The objectives of the study are: (1) to evaluate the financial feasibility of agroforestry techniques employed by farmers in Andhra Pradesh and Madhya Pradesh, India; and (2) to examine factors affecting the financial feasibility of agroforestry schemes in these regions. Education attained by farmers shows a wide disparity between the regions. In region 2, all farmers had a ninth grade education or above. It is interesting that over $50 \%$ of the farmers in region 1 had no education. This is possibly due to the fact that a high proportion of farmers interviewed in this region are tribal people, and has little access to education. Nkonya et al. (2004) in a study of landowners in Uganda, suggest that higher education levels of farmers influences household income strategy, land management practices and labor use in crop production. Higher education obtained led to higher income and reduced soil nutrient depletion. In the Sudan, it was found that adoption of new technologies increased with higher education levels of the farmers (Glover, 2005). The farmers in region 2 appeared to be better off financially, based on living arrangements and household characteristics. Although information on total income was not gathered, it was apparent that the farmers in Region 2 were better off financially, possibly relating to the education they had attained.

In region 1, the females which were interviewed were tribal people. The customs of these tribes was a matriarchal system, where the men traveled for work and the women stayed at home in charge of the household and the land. These women were involved in the eucalyptus planting because they were approached by the company and a local NGO in order to utilize their land and 
gain additional income. Only males were interviewed in region 2 . This was due to the customs of the area, being that males were the head of household and dominant in the farming community.

Farmers have started planting in higher number within the last few years. As mentioned before, the company pushed for development of new plantations within the last ten years. The most recent surge of plantations was to meet the increased demand of the company mill. In region 2, planting has only begun since 2006 . This is due to the company interest in building a new mill in the area. The company decided to begin developing plantations in the region for wood source for the new mill. Another reason for plantation development in region 2 was the competing market of the pole market in the region. Farmers from Region 1 would sell the polesize trees in region 2 in order to increase their profit. This practice was reducing the supply of pulp wood to the mill. The company decided that it would be advantageous to develop plantations in region 2 in order to reduce the losses from region 1.

Plowing occurred on more than two thirds of the farms in this study. This practice was one of the most important, as recommended by the company. Plowing reduces the competition between rows of eucalyptus and provides protection from fires. Most of the farmers interviewed had grown crops on their lands prior to the eucalyptus plantations; therefore many were familiar with plowing techniques. The main purpose of plowing between rows is to reduce the competition from weeds or grasses which would otherwise grow in the open space. These weeds would reduce the water and nutrients that are available to the trees. In addition, the weeds and grasses produce a fire hazard to the trees. When the grasses are dry they are very flammable, as is the eucalyptus. Open fires in India are very common and several farmers and company personnel expressed concern about plantations suffering from fire damage. Reasons for not plowing included a lack of access to equipment or animals to carry out the plowing, or a lack of 
money to afford renting or borrowing equipment. Plowing was either conducted mechanically or by the use of draft animals. It is not known exactly what percentage of farmers in region 1 used tractors and what percentage used draft animals, but from observations, it is estimated that roughly half used each method of plowing. In region 2, all farmers who plowed, used tractors to plow their fields.

It is interesting that cultivation was so low in region 2. Cultivation should be simple to do with mechanical means, since it is another attachment to the tractor. However there was no cultivation done in this region. This lack of cultivation could be because of lack of time or money since cultivating would require more effort spent in the field and more money. It is also possible that farmers were not interested in purchasing the additional equipment needed to cultivate their land. In region 1, although few farmers cultivated, more did so than in region 2 where mechanical methods were more prevalent.

Fertilization occurred on half of the farms in region 1 and on none of the farms in region 2. The main reason for lack of fertilization was the cost associated with purchasing the fertilizer. In addition, some farmers expressed a problem of accessing fertilizer even though they could afford it. Although both of the regions are heavily agricultural regions, fertilizer was scarce or expensive. The company recommends fertilizing in order to maximize the growth of the trees.

Irrigation as well is recommended by the company in order to maximize growth. However, very few farmers irrigated their land because of the extreme cost associated with it. The majority of the farms were rain fed and received rain only during the rainy season. Many farmers said they had not received rain in a period of 7 or 8 months, from late 2008 to early 
2009. The lack of rain led to some of the problems associated with the tree plantations such as breakage and wind damage.

With the lower number of trees, the $3 \times 2 \mathrm{~m}$ and $2.74 \times 1.37 \mathrm{~m}$ spacing scheme was favorable to farmers because it requires a lower up-front cost. These spacing options were only used in region 1 because the farmers in that area were not interested in having an intercrop after the first year. One factor in the reason for farmers to change from traditional crops to eucalyptus is the problem of finding labor to plant and harvest the traditional crops. If farmers continue to plant these traditional crops for multiple years along with the eucalyptus planting, then they would encounter the same problem. The farmers though, were willing to deal with this problem for the first year in order to help offset the eucalyptus planting costs. In region 1, the $3 \mathrm{~m} \times 1.5 \mathrm{~m}$ spacing was used with a first year intercrop because farmers believed that it created too much shade for any intercrop to grow under. However, in region 2 farmers planted a shade tolerant grass species as an intercrop in multiple years. The farmers in region 2 were more interested in continuing their traditional crops than farmers in region 1. For this reason, they were intercropping longer, and adapting spacing schemes to fit their desires.

The $8 \times 1 \times 1 m$ and $3 \times 1 \times 1 m$ spacing schemes involve a wide area between the paired row, and a tightly grouped pair of rows of trees. This allows for a more open area to grow an intercrop in, and in the case of the farmers interviewed, to grow crops for all years of the rotation. These spacing types were recommended to the farmers in this region because they were reluctant to convert their traditional crop lands to eucalyptus. The farmers were interested in continuing to grow their traditional crops and in order for the company to persuade them to grow trees, they approached the farmers with these paired row spacing schemes. 
Although these agroforestry systems are beneficial economically to the farmers who are involved, there may be better options (Saxena, 1992). One problem with the eucalyptus trees is the lack of fodder for animals. There are possible species that could provide tree cover and raw materials, fodder and food for humans, such as Leucaena, Prosopis cineraria or Acacia nilotica. In addition, farmers need to be better educated on the risks of eucalyptus, such as fire and pest and disease, and tree planting in general, before they undertake these schemes. Many of the farmers interviewed believed that the tree plantations were less risky than traditional agriculture. This may not always be the case due to pests, disease, fires and other problems along with the longer term rotation.

Another problem, addressed by only one farmer, although very important, is converting the land out of plantations. Uprooting and removing the stumps of the eucalyptus can be a very expensive and time consuming effort. This did not appear to be a factor in most of the farmers' considerations of planting. However, it is important to note that removing the tree stumps from a field is much different than removing the traditional crop residue most farmers are accustomed to and will require high levels of labor and time.

Initial investment is high for the agroforestry schemes examined. The large upfront costs associated with planting the eucalyptus may deter farmers from planting. Net returns for the first year were negative for both regions. In region 2, where an intercrop was grown for the entire rotation, positive net returns were realized after the first year. The income from intercropping in the first year does help to offset the costs, but cannot overcome the high costs for planting eucalyptus. 
In the study by Jain and Singh (2000) in poplar (Populus deltoides), they found BC ratios of 1.01 to 1.35 and IRR values of $14 \%$ to $32 \%$ for agroforestry based systems. They also found $\mathrm{BC}$ ratios for a number of different crops, from 1.22 in Paddy-Gram systems to 1.17 in Groundnut-Gram systems, which are common systems in the Andhra Pradesh and Madhya Pradesh areas. The $\mathrm{BC}$ ratios they found range from 1.14 to 2.47 for a wide variety of crop systems. The BC ratios from the eucalyptus agroforestry systems in this study are very similar to these values. Region 1 had a $\mathrm{BC}$ ratio ranging from 1.86 to 2.09 , with a $16 \%$ and $6 \%$ discount rate respectively. Region 2 however has much higher $\mathrm{BC}$ ratios ranging from 6.93 to 8.04 due to the high revenue from selling their product as poles, using a $16 \%$ and $6 \%$ discount rate respectively. IRR values in the poplar agroforestry schemes reported by Jain and Singh were $32.4 \%$ and $16.02 \%$. IRR values for this study in region 1 was $28 \%$ and in region 2 was $74 \%$.

This study examined only the first cutting cycle of the eucalyptus. In subsequent cycles, returns will be higher due to the sprouting of eucalyptus. Planting of eucalyptus is not needed which will reduce the costs in the first year, since only a small cost of trimming the sprouts is needed. In many cases, this trimming can actually be profitable since there is a high demand from private nurseries for shoots. The sale of these shoots can generate income and raise the profitability of the system. The company recommends a four cycle rotation, of four year cycles. This would mean that the complete genet would be 16 years.

Further research should be done on the social aspects of farmers involved in agroforestry in this study area. Research into the interaction of animals should also be further investigated. Multiple farms were located in this study where animals were involved in the farming systems; however it was difficult to place values on the impact of these animals. These aspects may have an impact on agroforestry systems. 
Regression results has shown that the financial feasibility (as measured by NPV) of converting traditional croplands into agroforestry systems in Andhra Pradesh and Madyha Pradesh, India are significantly influenced by region, the starting year of agroforesty establishment, plowing cost, irrigation cost, spacing, trees per acre, number of intercrops used, type of intercrops used, intercrop cost, intercrop revenues, and eucalyptus plantation revenues.

The region variable was hypothesized to be positive because it was thought that Madhya Pradesh was more profitable than Andhra Pradesh. The Madhya Pradesh region had higher values for the material and it shows that by being in this region, farmers can gain from these higher values, leading to higher NPVs. As hypothesized, spacing and trees per acre were positively related to NPV because they represent more raw materials per acre. The higher value for the spacing option relates to the area that a single tree occupies. The higher the number, the less space a tree occupies. This more open spacing allows for intercrops to be grown for a longer period of time, leading to higher NPV. Trees per acre also positively influence the NPV because a higher number of trees potentially means more volume, and therefore more revenue at a sale. Starting year was negatively related to NPV because more recent planting have benefited from advancements in clonal technology, such as trees that produce more fiber in less time. More recent planting by farmers have also benefited from learning from the mistakes that other farmers have made and tailoring their agroforestry systems to avoid these problems.

It is interesting that cotton has a negative relationship with NPV. It was the most popular intercrop used by farmers, although only used in Andhra Pradesh. It was assumed that cotton would have a positive impact on NPV since it was such a common intercrop, which farmers were planting because of perceived high value. The results of the regression indicate that farmers would be better off by using other intercrops such as such as chili, tobacco or tomato, instead of 
cotton. However, these intercrops were lumped into one category in the model, there may be some that perform better than others.

Plowing cost was hypothesized to be negative because it is a cost. However, the regression model shows that it is a positive influence on the NPV, meaning that higher costs for plowing lead to higher NPV. This is likely because plowing reduces the competition between rows of eucalyptus from weeds or grasses which would otherwise grow in the open space. These weeds would reduce the water and nutrients that are available to the trees. So more money, and time, spent on plowing will lead to reduced competition and better soil characteristics for the eucalyptus to grow. 


\section{Summary and Conclusions}

This study has identified different agroforestry systems under ITC promotion, used in Andhra Pradesh and Madhya Pradesh. The economic analysis confirms that the systems are feasible, with Madhya Pradesh being more profitable. Regression analysis has shown the strong relationships between region, costs and the spacing option and NPV. The more profitable system appears to be Madhya Pradesh

Education attained by farmers shows a wide disparity between the regions. In region 2, all farmers had a ninth grade education or above, whereas over 50\% of the farmers in region 1 had no education.

Average field size overall was 6.4 acres. In region 1, average farm size was 4.8 acres and in region 2 the average was 11.6 acres. In region 1, the earliest planting establishment by farmers interviewed was in 1991. Region 1 follows the overall planting trend very closely, having the highest planting percentage in 2006 with 27.8\%. Planting in region 2 started in 2006 but most (45.5\%) of the farmers interviewed did not start establishing plantation until 2008. Overall, the average trees per acre planted by farmers were 791.9. In region 1, the mean trees per acre were on average 730.6 trees and 992 in region 2. Overall, rotation age on average was 4.06 years. In region 1 the mean rotation age was 4.14 years and 3.82 years in region 2 .

Overall, $80 \%$ of the farmers interviewed conducted plowing. The company recommends plowing in order to increase production from the eucalyptus by aeration of the soil, water conservation and protect from competing grasses. When the grasses are dry they are very flammable, as is the eucalyptus. Open fires in India are very common and several farmers and 
company personnel expressed concern about plantations suffering from fire damage. Reasons for not plowing included a lack of access to equipment or animals to carry out the plowing, or a lack of money to afford renting or borrowing equipment. About $75 \%$ of the farmers in region 1 plowed their plantations and about $91 \%$ of the farmers in region 2 plowed theirs.

Overall, cultivation occurred on only $4 \%$ of the farms. In region 1 , nearly $6 \%$ of farmers cultivated while only $4 \%$ cultivated in region 2 . Overall, only $38 \%$ of the farmers applied fertilization while the majority did not fertilize. However, looking only at region $1,50 \%$ of the farmers fertilized and 50\% did not fertilize. In region 2, no farmers fertilized. The farmers are advised to fertilize in the form of NPK twice every year, however fertilizer was reported by the farmers to be too expensive to purchase or unavailable. Overall, $8.5 \%$ of the farmers irrigated their farms. In fact, only farmers from region 1 applied irrigation (11\%) while none of the farmers in region 2 irrigated. Irrigation was limited because of the expense associated with it, according to the farmers. The application of insecticide occurred on only $2 \%$ of the overall farms. The application of Phorate is recommended at the time of planting to protect saplings against root grub. In region 1,3\% of farmers applied insecticide and in region 2, no farmers applied insecticide.

The research shows five variations on spacing techniques used in the study area. These spacing options are $3 \mathrm{~m} \times 2 \mathrm{~m}, 2.74 \times 1.37 \mathrm{~m}, 3 \mathrm{~m} \times 1.5 \mathrm{~m}, 8 \mathrm{~m} \times 1 \mathrm{~m} \times 1 \mathrm{~m}$ and $3 \mathrm{~m} \times 1 \mathrm{~m} \times 1 \mathrm{~m}$. The $8 \mathrm{x} 1 \mathrm{x} 1$ and $3 \mathrm{x} 1 \mathrm{x} 1$ spacing patterns are in a paired row format, meaning that there is $8 \mathrm{~m}$ or $3 \mathrm{~m}$ respectively between two rows and $1 \mathrm{~m}$ between each row and tree in that row. The $3 \times 2$ and $2.74 \times 1.37 \mathrm{~m}$ were only used in region $1,3 \times 1.5$ was used in both regions and the two paired rows $8 \times 1 \times 1$ and $3 \times 1 \times 1$ were only used in region 2. 
Overall, intercrops were used $83 \%$ of the time. Seventeen percent of the farmers interviewed did not plant an intercrop along with their eucalyptus plantations. In region 1, nearly $78 \%$ of the farmers planted an intercrop compared to $22 \%$ that did not. In region 2 , all farmers planted an intercrop. The most common intercrop was cotton, planted by 17 farmers. Other common intercrops were chili, black gram, tobacco, and multiple combinations of crops.

Overall, the average eucalyptus yield was 28.2 tons per acre. In region 1, the mean yield was on average 24.3 tons/ac while in region 2, the mean yield was 40.9 tons/ac. The overall average eucalyptus price per ton was $\$ 49.40$. In region 1 , the mean price was $\$ 39.30$. In region 2 , the mean price was higher with farmers receiving $\$ 82.40$ per ton.

Based on the positive values of NPV, BCR, EAI, and LEV, converting traditional croplands to agroforestry are financially feasible using $12 \%$ discount rate. In addition, IRR in both regions are greater that the discount rate used in the study, indicating the feasibility of the system. The $\mathrm{BC}$ ratios from the eucalyptus agroforestry systems in this study range from 1.86 to 2.09 , with a $16 \%$ and $6 \%$ discount rate respectively. Region 2 however has much higher BC ratios ranging from 6.93 to 8.04 due to the high revenue from selling their product as poles, using a $16 \%$ and $6 \%$ discount rate respectively. IRR values in the poplar agroforestry schemes reported by Jain and Singh were $32.4 \%$ and $16.02 \%$. IRR values for this study in region 1 was $28 \%$ and in region 2 was $74 \%$.

Factors that significantly influence the feasibility of converting traditional croplands into agroforestry system include region, the starting year of agroforesty establishment, plowing cost, irrigation cost, spacing, trees per acre, number of intercrops used, type of intercrops used, intercrop cost, intercrop revenues, and eucalyptus plantation revenues. Farmers who converted to 
agroforestry plantation recently tended to have higher NPV as shown by the negative sign of the starting year variable. NPV is positively influenced by both the intercrop and eucalyptus plantation revenues, as expected. Spacing and trees per acre also positively influenced NPV. The larger the spacing and the more trees per acre planted, the higher the NPV. The results of the model also indicate that farmers in Madhya Pradesh have higher NPVs. The number of intercrops used also positively influenced NPV. The more intercrops planted by the farmers, the higher the NPV. In terms of the type intercrops used, farmers using cotton as an intercrop tended to have lower NPV compared to farmers using other agricultural crops such as chili, tomato, etc. Most of the variables representing costs of farm practices, as expected, have a negative influence on NPV. However, plowing cost had a positive influence on NPV, contrary to expectation. Farmer characteristics such as education and gender are not significant factors as well as other cost variables like fertilization, irrigation and planting costs. Size of the farm is also not a significant determinant of the feasibility of agroforestry.

Although this study provides useful information on industrial promoted agroforestry, there are some limitations. First, all of the farmers interviewed were recommended by company personnel and were interviewed in the presence of company personnel. This has the possibility to limit the exposure to a more diverse representation of farmers. Farmers may have been selected due to performance and not randomly. Farmers may not have been completely straight-forward in interviews due to the fact that they were conducted in the presence of company personnel. This could be rectified by conducting the research with limited assistance of company personnel.

Language as well was a limitation in communicating with farmers. The majority of farmers did not speak English so a translator was necessary. This was almost always the company personnel. It is possible that details could have been misunderstood or left out due to 
the translations that occurred, or translator/researcher/farmer miscommunication. This problem could be prevented by knowledge of the language, or use of a third party interpreter.

Sample size is also a limitation to this study. Thirty-six farmers in Andhra Pradesh and only 11 farmers were interviewed in Madhya Pradesh. A larger sample size could provide further insight into the characteristics of the landowners. This could also prevent from any bias or outliers in the data collected. 


\section{Work Cited}

"Andhra Pradesh." Encyclopædia Britannica. 2009. Encyclopædia Britannica Online. 05 Sep. 2009 <http://www.britannica.com/EBchecked/topic/23752/Andhra-Pradesh>.

"Annual Rainfall of India Map." Maps of India. 24/09/2009. Compare Infobase Limited, Web. 24 Sep 2009. 〈http://www.mapsofindia.com/maps/india/india-political-map.htm>.

Arnold, J.E.M. "Economic considerations in agroforestry "In Agroforestry a decade of development, Edited by H.A. Steppler and P.K.R. Nair. Nairobi, Kenya: ICRAF House, 1987.

Ball, J.B. Development of Eucalyptus Plantations-An Overview. Reports Submitted to the Regional Expert Consultation on Eucalyptus. Bangkok: FAO, 1996.

Beer, John. "Advantages, disadvantages and desirable characteristics of shade trees for coffee, cacao and tea." Agroforestry Systems 5(1987): 3-13.

Bertomeu, Manuel G. Smallholder maize-timber agroforestry systems in Northern Mindanao, Philippines: Profitability and contribution to the timber industry sector. The International Conference on Rural Livelihoods, Forests and Biodiversity, Bonn, Germany. Bonn, Germany: 2003.

Ceccon, Eliane. "Eucalyptus agroforestry system for small farms: 2-year experiment with rice and beans in Minas Gerais, Brazil." New Forests. 29. (2005): 261-272.

Centre for Science and Environment (CSE). 1985. The state of India's environment. The second citizen's report. New Delhi: CSE.

Davidson, John. Ecological Aspects of Eucalyptus Plantations. Reports Submitted to the Regional Expert Consultation on Eucalyptus. Bangkok: FAO, 1996.

FAO. 2005. State of the World's Forests. Rome.

Glover, E.K. 2005. Tropical dryland rehabilitation Case study on participatory forest management in Gedaref, Sudan. Doctoral thesis. University of Helsinki, Department of Forest Ecology, Viikki Tropical Resources Institute (VITRI). 183 p.

Imo, Moses. "Interactions amongst trees and crops in taungya systems of western Kenya." Agroforestry Systems. 76.2 (2009): 265-273.

"India Political Map." Maps of India. 24/09/2009. Compare Infobase Limited, Web. 24 Sep 2009. <http://www.mapsofindia.com/maps/india/india-political-map.htm>. 
"India Annual Temperature Map." Maps of India. 24/09/2009. Compare Infobase Limited, Web. 24 Sep 2009. <http://www.mapsofindia.com/maps/india/india-political-map.htm>.

ITC Limited. Paperboards and Specialty Papers Division. Making Nature and People smile. Bhadrachalam: 2007

Jain, S.K., and P. Singh. "Economic analysis of industrial agroforestry: poplar (Populus deltoides) in Uttar Pradesh (India)." Agroforestry Systems. 49. (2000): 255-273.

Jain, Sobhita. "Case studies of Farm Forestry and Wasteland Development in Gujarat, India." Community Forestry Case Study Series 01(1988)

Kashio, M. A Regional Overview of Eucalyptus Planting and the Scope of the Present Consultation-Based on the Presented Papers. Reports Submitted to the Regional Expert Consultation on Eucalyptus. Bangkok: FAO, 1996.

Kongsom, Chaiwat, Ian A. Munn. "Optimal Rotation of Eucalyptus Plantation In Thailand Based on Financial Return and Risk." Forest and Wildlife Research Center Journal (2002): 179-183.

Lal, Piare. "Integrated Development of Agroforestry Plantations and Wood Based Industries" in Agroforestry In $21^{\text {st }}$ Century, Edited by S.K. Chauhan, S.S. Gill, S.C. Sharma and R. Chauhan. New Delhi, India: S.S.S. Printers, 2005.

Long, Alan J., and P.K.R. Nair. "Trees Outisde Forests: agro-, community, and urban forestry." New Forests 17(1999): 145-174.

Lundgren, B.O. and J. B. Raintree. "Sustained Agroforestry" in Agricultural Research for Development: Potentials and Challenges in Asia. ISNAR, The Hague, The Netherlands. 1982.

"Madhya Pradesh." Encyclopædia Britannica. 2009. Encyclopædia Britannica Online. 05 Sep. 2009 <http://www.britannica.com/EBchecked/topic/355793/Madhya-Pradesh>.

Mercer, D.E. and Miller, R.P. 1998. Socioeconomic research in agroforestry: progress, prospects, priorities. Agroforestry Systems, 38: 177-193

Nair, P.K.R. 1993. An introduction to agroforestry. Dordrecht, Netherlands, Kluwer Academic Publishers.

Niskanen, Anssi. "Financial and economic profitablitiy of reforestation in Thailand." Forest Ecology and Management 104(1998): 57-68.

Nkonya, E., Pender, J., Jagger, P., Sserunkuuma, D., Kaizzi, C. and Ssali, H. 2004. Strategies for sustainable land management and poverty reduction in Uganda. Research Report 133. International Food Policy Research Institute. Washington D.C. 136 p. 
"North East Monsoon of India Map." Maps of India. 24/09/2009. Compare Infobase Limited, Web. 24 Sep 2009. <http://www.mapsofindia.com/maps/india/india-politicalmap.htm>.

Palanna, R.M. Eucalyptus in India. Reports Submitted to the Regional Expert Consultation on Eucalyptus. Bangkok: FAO, 1996.

Patil, Vinayakrao. Local Communities and Eucalyptus-An Experience in India. Reports Submitted to the Regional Expert Consultation on Eucalyptus. Bangkok: FAO, 1996.

Pruchapruth, Suthenun. The Role of Eucalyptus-Current Problems in Thailand. Reports Submitted to the Regional Expert Consultation on Eucalyptus. Bangkok: FAO, 1996.

Raintree, John B. The Great Eucalyptus Debate: What is it Really All About. Reports Submitted to the Regional Expert Consultation on Eucalyptus. Bangkok: FAO, 1996.

Reyes, Teija. (2008). Agroforestry systems for sustainable livelihoods and improved land management in the East Usambara Mountains, Tanzania. Unpublished doctoral dissertation. University of Helsinki, Dept. of Agriculture and Forestry. 166 p.

Saxena, Naresh C. "Farm Forestry and Land-use in India: Some Policy Issues." Ambio. 21.6 (1992): 420-425.

Schroeder, Paul. "Agroforestry systems: integrated land use to store and conserve carbon." Climate Research. 3. (1993): 53-60.

Singh, G.B. "Agroforestry in the Indian subcontinent: past, present and future" In Agroforestry a decade of development, Edited by H.A. Steppler and P.K.R. Nair. Nairobi, Kenya: ICRAF House, 1987.

Spears, John. "Agroforestry: a development-bank perspective" In Agroforestry a decade of development, Edited by H.A. Steppler and P.K.R. Nair. Nairobi, Kenya: ICRAF House, 1987.

Steppler, Howard A. "ICRAF and a decade of agroforestry development." In Agroforestry a decade of development, Edited by H.A. Steppler and P.K.R. Nair. Nairobi, Kenya: ICRAF House, 1987.

Stoler, A. 1978. Garden use and household economy in rural Java. Bulletin of Indonesian Studies 14:85-101.

"South West Monsoon of India Map." Maps of India. 24/09/2009. Compare Infobase Limited, Web. 24 Sep 2009. <http://www.mapsofindia.com/maps/india/india-politicalmap.htm>. 
Straka, Thomas J., and Steven H. Bullard. "Land Expectation Value in Timberland Valuation." Appraisal Journal. (1996): 399-405.

Sungsumarn, Komain Why Eucalyptus is Not Adopted for Agroforestry. Reports Submitted to the Regional Expert Consultation on Eucalyptus. Bangkok: FAO, 1996.

Swaminathan, M.S. "The promise of agroforestry for ecological and nutritional security" In Agroforestry a decade of development, Edited by H.A. Steppler and P.K.R. Nair. Nairobi, Kenya: ICRAF House, 1987.

Turnbull, John W. "Eucalypt plantations." New Forests 17(1999): 37-52.

Veracion, A.G. 1983. Agroforestry: The Paper Industries Corporation of the Philippines' experience. Agroforestry in perspective. Los Banos, Laguna, Philippines: PCARRD

White, K.J. Silviculture of Eucalyptus Plantings-Learning in the Region. Reports Submitted to the Regional Expert Consultation on Eucalyptus. Bangkok: FAO, 1996.

World Resources Institute (WRI). 1985. Tropical forests: a call for action. Part I. Washington, D.C. WRL 
Appendix A 
Table 13. Financial analysis of converting traditional agricultural croplands to agroforestry in Andhra Pradesh, India, 2009.

Year

\begin{tabular}{|c|c|c|c|c|c|c|c|c|c|c|c|c|c|c|}
\hline $\begin{array}{l}\text { Intercrop } \\
\text { Planting }\end{array}$ & $\begin{array}{c}\text { Intercrop } \\
\text { Harvest }\end{array}$ & $\begin{array}{l}\text { Euca } \\
\text { Planting }\end{array}$ & Plowing & Cultivation & Fertilizer & $\begin{array}{l}\text { Irrig- } \\
\text { ation }\end{array}$ & FYM & $\begin{array}{l}\text { Insect- } \\
\text { icide }\end{array}$ & $\begin{array}{l}\text { Harvest } \\
\text { Euca }\end{array}$ & Total Cost & $\begin{array}{c}\text { Total } \\
\text { Benefit }\end{array}$ & $\begin{array}{c}\text { PV } \\
\text { Costs }\end{array}$ & $\begin{array}{c}\text { PV } \\
\text { Benefits }\end{array}$ & NPV \\
\hline \multirow[t]{5}{*}{-219.8} & 367.1 & -31.9 & -25.8 & -12.5 & -20.7 & -32.8 & -12.5 & -16.7 & & -372.7 & 367.1 & -372.70 & 367.10 & \\
\hline & & & -25.8 & -12.5 & -20.7 & -32.8 & -12.5 & & & -104.3 & 0 & -93.13 & 0.00 & \\
\hline & & & -25.8 & -12.5 & -20.7 & -32.8 & -12.5 & & & -104.3 & 0 & -83.15 & 0.00 & \\
\hline & & & -25.8 & -12.5 & -20.7 & -32.8 & -12.5 & & 1185.75 & -104.3 & 1185.75 & -74.24 & 843.99 & \\
\hline & & & & & & & & & & & & -623.21 & 1211.09 & 587.88 \\
\hline
\end{tabular}


Table 14. Financial analysis of converting traditional agricultural croplands to agroforestry, Madhya Pradesh, India, 2009.

\begin{tabular}{|c|c|c|c|c|c|c|c|c|c|c|c|c|c|c|}
\hline $\begin{array}{l}\text { Intercrop } \\
\text { Planting }\end{array}$ & $\begin{array}{c}\text { Intercrop } \\
\text { Harvest }\end{array}$ & $\begin{array}{c}\text { Euca } \\
\text { Planting }\end{array}$ & Plowing & Cultivation & Fertilizer & Irrigation & FYM & Insecticide & $\begin{array}{c}\text { Harvest } \\
\text { Euca }\end{array}$ & $\begin{array}{l}\text { Total } \\
\text { Cost }\end{array}$ & $\begin{array}{c}\text { Total } \\
\text { Benefit }\end{array}$ & $\begin{array}{c}\text { PV } \\
\text { Costs }\end{array}$ & $\begin{array}{c}\text { PV } \\
\text { Benefits }\end{array}$ & NPV \\
\hline-99.40 & 158.90 & -51.70 & -43.80 & 0.00 & 0.00 & 0.00 & 0.00 & 0.00 & & -194.90 & 158.90 & -194.90 & 158.90 & \\
\hline-106.00 & 379.80 & & -43.80 & 0.00 & 0.00 & 0.00 & 0.00 & 0.00 & & -149.80 & 379.80 & -133.75 & 339.11 & \\
\hline \multirow[t]{3}{*}{-78.50} & 356.80 & & -43.80 & 0.00 & 0.00 & 0.00 & 0.00 & 0.00 & & -122.30 & 356.80 & -97.50 & 284.44 & \\
\hline & 260.40 & & -43.80 & 0.00 & 0.00 & 0.00 & 0.00 & 0.00 & 3361.70 & -43.80 & 3622.10 & -31.18 & 2578.14 & \\
\hline & & & & & & & & & & & & -457.32 & 3360.59 & 2903.26 \\
\hline
\end{tabular}


Appendix B 
Survey Draft for personal interview with farmers

Brian McDonald

May 8, 2009

\section{Demographic Information}

1. What is your gender?

_ Male __ Female

2. What is your age?

3. What is your highest educational attainment?

less than high school

high school graduate

some college, no degree

associates degree

bachelors degree

graduate or professional degree

4. How many members are in your household?

5. What is the population of the village you live in?

Name of the Village:

6. In addition to farming, do you have other sources of income?

Yes No

7. What is your monthly income in your household?

\section{Property Information}

1. How many hectares of land do you own?

2. Do you rent or own your land or is it community owned?

3. How much of your land is used for agroforestry?

4. Prior to conversion to agroforestry, what previous crops have been planted on the land?

5. What percentage of total income does this land make up? In other words, is this land your only/main source of income? 
III. Agroforestry Information

1. How long have you been practicing agroforestry in your land?

2. Why did you convert to AF?

Money, labor constraints, other incentives

3. How did you hear about this technique?

Company advertising, neighbors, personal interest

4. How many labor hours per week are spent on the farm?

5. What activities occur?

Weeding, maintenance, etc

6. What is the planting design, and why was this chosen?

7. Are there any systems that would be preferred?

8. Arrangement of trees

Strips, blocks, border etc

9. What type of agroforestry are you using?

Agrosilvi, silvopastoral, agrosilvopastoral

10. Number of seedlings per hectare? (or tree/crop spacing)

11. What tree and agricultural species (maybe crops or animals) species are you using in your agroforestry farm? What is the rotation of your tree species? How about your agricultural crops?

12. Why use this selection of species/species combination?

13. Is there a tree farmer cop-op in the region?

14. Have the planting materials been easily available to you? 
15. Have you entered into a contract with ITC?

Why or why not? Please provide details.

16. Have you used the company extension services? If yes, what types of services?

Help planting, education/teaching, activities, soil testing

17 Have you had any problems with AF system used?

\section{Economic Information}

1. How did you finance your AF system to begin?

Company help, local bank, community

2. Planting costs

Site prep

Digging

Weeding, etc

3. Consulting/company extension costs

4. Seedling Costs

5. Yield information per rotation

Tree Volume:

Agricultural Yield (crops or animals):

6. Harvesting costs

7. Harvest revenues

Price per unit of agricultural crops

Price per unit of tree crops 